\title{
Model Documentation Report \\ Short-Term Hydroelectric Generation Model
}

December 1996

\section{RECEIVED \\ JAN 161997 \\ OSTI}

Energy Information Administration

Office of Coal, Nuclear, Electric and Alternate Fuels

U.S. Department of Energy

Washington, DC 20585

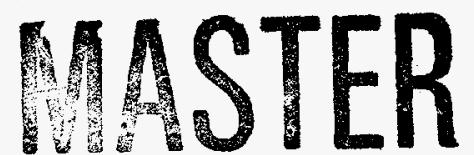


Released for Printing: December 26, 1996 


\section{DISCLAIMER}

This report was prepared as an account of work sponsored by an agency of the United States Government. Neither the United States Government nor any agency thereof, nor any of their employees, makes any warranty, express or implied, or assumes any legal liability or responsibility for the accuracy, completeness, or usefulness of any information, apparatus, product, or process disclosed, or represents that its use would not infringe privately owned rights. Reference herein to any specific commercial product, process, or service by trade name, trademark, manufacturer, or otherwise does not necessarily constitute or imply its endorsement, recommendation, or favoring by the United States Government or any agency thereof. The views and opinions of authors expressed herein do not necessarily state or reflect those of the United States Government or any agency thereof. 


\section{DISCLAMMER}

Portions of this document may be illegible in electronic image products. Images are produced from the best available original document. 


\title{
Model Documentation Report: Short-Term Hydroelectric Generation Model
}

\author{
Introduction
}

\section{Purpose of the Report}

The purpose of this report is to define the objectives of the Energy Information Administration's (EIA) Short-Term Hydroelectric Generation Model (STHGM), describe its basic approach, and to provide details on the model structure. This report is intended as a reference document for model analysts, users, and the general public. Documentation of the model is in accordance with the EIA's legal obligation to provide adequate documentation in support of its models (Public Law 94-385, Section 57.b.2).

\section{Model Summary}

The STHGM performs a short-term (18 to 27-month) forecast of regional (Census Division) hydroelectric generation in the United States using an autoregressive integrated moving average (ARIMA) time series model with precipitation as an explanatory variable. The model results are used as input for the Short-Term Energy Outlook.

\section{Model Archival Citation}

The STHGM is archived on the Energy Information Administration mainframe system and is available through the sponsoring office. The model contact is:

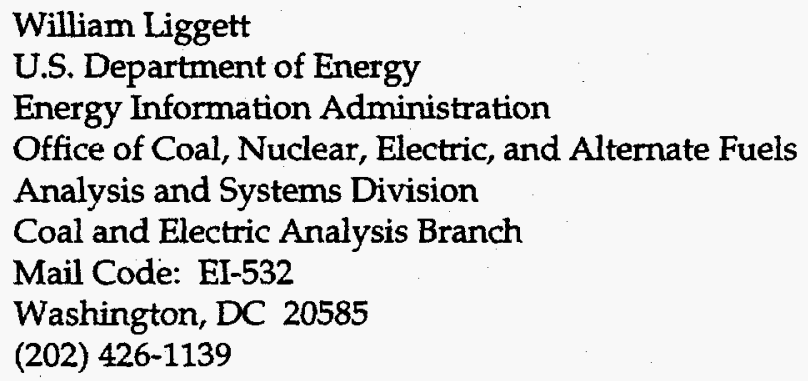

\section{Report Organization}

The remainder of this report is organized in the following manner: (1) model purpose, (2) model rationale, (3) model structure, (4) properties of the mathematical solution, (5) calibration and sensitivity analysis, (6) documentation of technical detail on the model data and equations, and (7) appendices.

\section{Model Purpose}

\section{Model Objectives}

The STHGM is used to provide quarterly projections of national hydroelectric generation for the Short-Term Energy Outlook. The model uses an ARIMA time series model with explanatory variables, otherwise known as a transfer 
function model, ${ }^{1}$ as the basis for its forecasting. The model is based on monthly historic data from 1970 to the present. The model also incorporates variations in precipitation as an explanatory variable.

\section{Model InputlOutput}

The STHGM uses both DOE and non-DOE data input sources. The DOE data are national totals of the plant-level net hydroelectric generation data reported monthly on the Form ELA-759, "Monthly Power Plant Report," and its predecessors. The historical dataset is updated prior the quarterly run of the model.

The non-DOE data are monthly precipitation data from the National Climatic Data Center. ${ }^{2}$ These data generally are released 6 months later than the generation data for a particular month. Also, precipitation data are not collected for Alaska and Hawaii. The hydroelectric generation for these two States is incorporated into the Pacific Region with the States of California, Oregon, and Washington. Generation in Alaska and Hawaii was less than 1 percent of total U.S. generation in 1994.

Forecasts of precipitation data are also required for the model. Monthly averages of data from 1970 to the present are used as "normal" precipitation. The monthly averages are calculated in a SAS program using data from the National Climatic Data Center.

The output data is an 18 to 27 -month forecast of net hydroelectric generation.

\section{Relationship to Other Models}

The STHGM does not directly interface with other EIA models; however, its forecast is utilized as input in the Short-Term Integrated Forecasting System (STIFS). The hydroelectric forecast is independent of other renewable and nuclear generation forecasts, but it does have an impact as an input to STIFS fossil fuel generation forecasts.

\section{Model Rationale}

\section{The Time Series Approach}

Time series models, which are used here, predict future generation (by region) as a function of past generation and account for trends and seasonality. No use is made of engineering knowledge or economic concepts in these models. Since a seasonal pattern is observed in historical monthly net hydroelectric generation data and the level of generation is affected by the availability of water, the STHGM is designed as an ARIMA time series model with the addition of two explanatory variables, precipitation and deterministic monthly seasonal dummies.

\section{Assumptions}

The STHGM uses an ARIMA time series model with precipitation as an explanatory variable. The model is based on normal ARIMA modelling assumptions. That is, the data are assumed to follow a model which is linear and time invariant with constant coefficients. Fixed monthly values are used to describe seasonality. Precipitation is assumed to be "normal" from the last month of available data forward. A monthly average for precipitation is calculated using data from 1970 to the latest available data, and this average is the assumed "normal" precipitation for that month.

\footnotetext{
'George E. Box and Gwilym Jenkins, Time Series Analysis, Forecasting and Control (1976).

21970-1992: National Climatic Data Center (NCDC), Disc. Resident Historical Divisional DataBase (DRD964X). These data are weighted by population using State and regional weights from the NCDC's State, Regional, and National Monthly and Annual Precipitation Weighted by Area for the Contiguous United States January 1931 - December 1987 (Asheville, NC, August 1988). The calculated data differ slightly from the published data due to updates of the State and regional weights. 1993-present: National Climatic Data Center, Monthly State, Regional and National Heating Degree Days Weighted by Population (Asheville, NC, March, 1989 through present), Table 3.3, "Regional and National Average Precipitation." These data are updated each time the model is run. Data are published weighted by population.

${ }^{3}$ Energy Information Administration, Electric Power Annual 1994 Volume I, DOE/ELA-0348(94)/1 (Washington, DC, July 1995), p. 25.
} 


\section{Alternative Approaches}

The previous approach for forecasting hydroelectric generation used by the Energy Information Administration was to use a purposive sample. For each month during the current water year, which ends September 30, or a nine-month period from presently available data if longer, hydroelectric generation projections were based upon information obtained by phone from 10 utilities/organizations representing eight U.S. geographic regions (Table 1). Generation in each region was projected to change by the same percentage as generation for the sample. That is, estimations for each of the forecast months was determined by calculating a monthly ratio of each utility's projected generation to its actual generation in the past year. This ratio was applied to the region's generation for the previous year to arrive at a projected value for the corresponding month of the current year. The regional projections were aggregated to obtain a national projection for generation.

Table 1. Hydroelectric Generating Regions

\begin{tabular}{|c|c|}
\hline Region & State \\
\hline 1 & $\begin{array}{l}\text { Connecticut, Delaware, District of Columbia, Maine, Massachusetts, New Hampshire, New Jersey, New } \\
\text { York, Pennsylvania, Rhode Island, Vermont. }\end{array}$ \\
\hline 2 & $\begin{array}{l}\text { Alabama, Florida, Georgia, Kentucky, Maryland, Mississippi, North Carolina, South Carolina, } \\
\text { Tennessee, Virginia, West Virginia, Alaska, Hawaii. }\end{array}$ \\
\hline 5 & Idaho, Oregon, Washington. \\
\hline 6 & $\begin{array}{l}\text { Arkansas, Illinois, Indiana, lowa, Kansas, Louisiana, Michigan, Minnesota, Missouri, Ohio, Oklahoma, } \\
\text { Texas, Wisconsin. }\end{array}$ \\
\hline
\end{tabular}

Hydroelectric generation in the succeeding years was assumed to be normal. Normal generation was calculated for conventional and pumped storage units by using capacity information from the Form EIA-860, "Annual Electric Generator Report," and historical monthly capacity factors averaged over 10 years.

This methodology included a considerable amount of analyst judgement the assessment of patterns and other factors, such as precipitation, weather, demand, or market conditions. Another shortcoming of this method was that different methodologies were used by the different sampled organizations.

In the development of the STHGM, the specific form of the model used for forecasting was selected from among reasonable alternatives of the same form including the use of regular and seasonal differencing. Another alternative to the use of monthly dummies to explain seasonality was also considered. First the periodogram of the generation data was examined and the seasonal frequencies having the greatest impact were selected. The seasonal mean was defined to be the sum of estimated coefficients multiplying the sine and cosine functions having these selected periodicities. The monthly dummy variable approach was adopted because it gave smaller root mean square error forecasts in the out of sample forecast evaluations (described in Calibration and Sensitivity Analysis, p. 7). These tests were run using a national level model only. Regional models were developed after the general form of the model had been chosen.

Another approach that was examined included the effects of trading day variations. The historic hydroelectric generation data were tested for trading day variation using the procedure X11 in SAS. The purpose of this test was to determine if the data needed to be adjusted for trading days, i.e., do hydroelectric facilities generate more on a Monday than on a Sunday. Any month can be looked at as having 28 days plus 0 to 3 extra different days of the week. Depending upon which days are extra, i.e. Monday and Tuesday or Saturday and Sunday, the net hydroelectric generation in a month could be affected. Tests at the 5 percent level indicated some trading day effect with the lowest generation on Sundays and the 
largest on Mondays and Tuesdays (Table 2). Tests of regional trading day variation using hydroelectric generation data for the 10 Census Divisions (Appendix C) indicated that while some trading day effect was noticeable, it was negligible. Therefore, the national data were not adjusted for trading day variation.

Further consideration might examine knowledge of current precipitation conditions instead of assuming normal precipitation throughout the forecast period. That is, the model could be modified to use average precipitation for low years or high years for sensitivity analysis.

Table 2. National Trading Day Variation Output

Final Trading Day Regression

\begin{tabular}{|c|c|c|c|c|c|c|}
\hline & $\begin{array}{c}\text { Combined } \\
\text { Weight }\end{array}$ & $\begin{array}{c}\text { Prior } \\
\text { Weight } \\
\end{array}$ & $\begin{array}{l}\text { Reg. } \\
\text { Coeff. }\end{array}$ & $\begin{array}{c}\text { St. Err. } \\
\text { Comb. Wt. }\end{array}$ & $\begin{array}{c}T \\
(1) \\
\end{array}$ & $\begin{array}{c}T \\
\text { Pr. Wt. }\end{array}$ \\
\hline Monday & 99.478 . & $* * * * * * *$ & 99.478 & 113.47 & 0.877 & $* * * * * * *$ \\
\hline Tuesday .................. & 104.71 & $\star \star \star \star \star * \star *$ & 104.710 & 111.63 & 0.938 & $* * * * * *$ \\
\hline 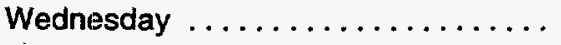 & 79.931 & 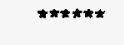 & 79.931 & 113.42 & 0.705 & $* * * * * *$ \\
\hline Friday $\ldots \ldots \ldots \ldots \ldots \ldots \ldots \ldots$ & -38.61 & $* * * * * *$ & -38.610 & 113.89 & -0.339 & $\star \star \star \star * \star * *$ \\
\hline Saturday $\ldots \ldots \ldots \ldots \ldots \ldots \ldots$ & 76.899 & $\star * * * * * * *$ & 76.899 & 112.77 & 0.682 & $* * \star * * * *$ \\
\hline Sunday $\ldots \ldots \ldots \ldots \ldots \ldots$ & -278.1 & $* * * * * *$ & -278.100 & 113.94 & -2.441 & ****** \\
\hline
\end{tabular}

* Comb. wt. differs from 1 at 1 percent level

** Comb. wt. differs from prior weight at 1 percent level

\begin{tabular}{|c|c|c|c|c|}
\hline $\begin{array}{l}\text { Source of } \\
\text { Variance }\end{array}$ & $\begin{array}{l}\text { Sum of } \\
\text { Squares }\end{array}$ & $\begin{array}{l}\text { Dgrs. of } \\
\text { Freedom }\end{array}$ & $\begin{array}{c}\text { Mean } \\
\text { Square }\end{array}$ & $\mathbf{F}$ \\
\hline Regression ..... & 5792155 & 6 & 965359.145 & 2.146 \\
\hline Error ......... & 116067925 & 258 & 449875.677 & \\
\hline Total .......... & 121860080 & 264 & & \\
\hline
\end{tabular}

Probability of a larger $F$ is .0487498

Std. Errors of Trading Day Adjustment Factors

\begin{tabular}{|c|c|}
\hline 31-day-month & 337.877 \\
\hline 30-day-month & 357.280 \\
\hline 29-day-month & 391.275 \\
\hline 28-day-month & 0.000 \\
\hline
\end{tabular}




\section{Model Structure}

\section{Flow Diagram}

The initial step of the STHGM is reading in the historical net hydroelectric generation and the precipitation data with a 3-year forecast of normal precipitation levels. The data are divided by the number of days in each month in order to account for the different lengths of the months. Next, the first ARIMA procedure is run to estimate the prewhitening model for precipitation. The second ARIMA model is run to estimate coefficients for the monthly dummy variables and the correlated lags of the precipitation data. The generation data are then adjusted using these coefficients to account for seasonality and the effects of precipitation. The ARIMA procedure is then run with the adjusted data which outputs the forecast. The forecast is multiplied by the number of days in each month and readjusted for seasonality and the effects of precipitation (Figure 1).

Figure 1. Flow Diagram of the STHGM

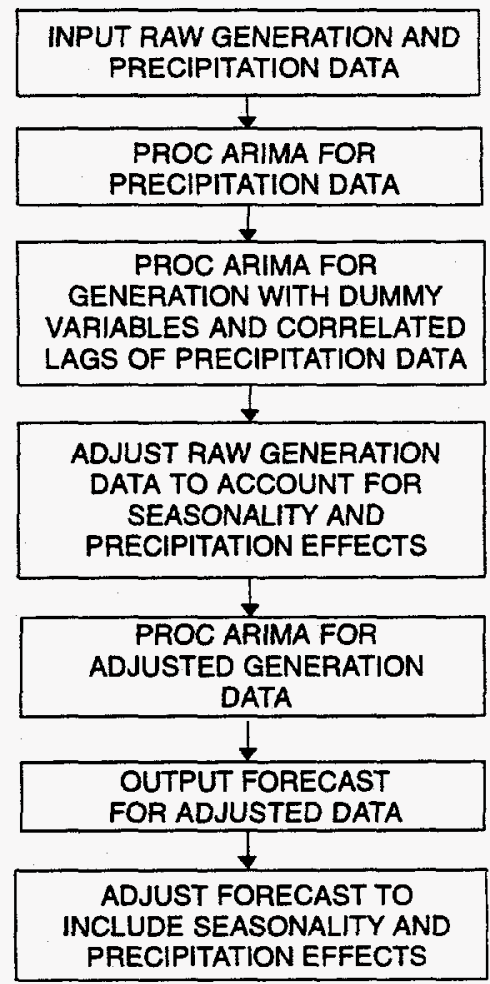

\section{List of Computations and Equations}

The time series models considered for this project come from the ARIMA family of models with explanatory variables. Model identification and estimation were done using PROC ARIMA in SAS version 6.08. In particular the model structure for the national model is of the form

$$
\Phi(B)\left(N A T T O N A L_{t}-\sum_{k=1}^{12} N U M_{k+1} D U M_{t, k}-v(B) R A I N N A T\right)=\Theta(B) a_{t}
$$


where,

NATIONAL ${ }_{t}$ is the national daily average hydro generation in month $t$

DUM $_{t, k}$ is a seasonal dummy variable which is zero unless observation $t$ is in month $k$, in which case it is one;

RAINNAT $_{t}$ is the national daily average precipitation in month $t$;

$\phi(B)$ is the autoregressive part of the model (Equation 6);

$\theta(B)$ is the moving average part of the model (Equation 7);

$v(B)$ is the transfer function part of the model (Equation 3); and

$\mathrm{NUM}_{\mathrm{k}+1}$ are the coefficients of the seasonal mean, where $\mathrm{k}=1$ is the coefficient for January.

Specific model structure was selected from this family of models based on standard diagnostics: the autocorrelation function, partial autocorrelation function, and inverse autocorrelation function of both the generation data and the model residuals, significant $t$-statistics for estimated parameters, the Portmanteau goodness of fit Chi square test for departures from model assumptions, the Akaike Information Criterion (AIC) to select the best from competing models, and comparisons of the model forecasts to actual data otherwise known as out-of-sample testing. ${ }^{4}$

The specific estimated parameters are shown in Table 3.

This model includes two functions which explain the time varying mean of the generation data: the first is the mean due to seasonal variation, the second is the mean due to the impact of precipitation. In particular, the average seasonal effect in month $t$ is given by

$$
M E A N S_{t}=\sum_{k=1}^{12} N U M_{k+1} D U M_{t, k}
$$

Where $\mathrm{NUM}_{\mathrm{k}+1}$ is the estimated parameter (Table 3) and DUM, is unchanged. The variance of the estimated seasonal mean in a month, VARS $_{t}$ is the square of the approximate standard error of the appropriate estimated coefficient (Table 3).

The transfer function part of the model describes the impact of precipitation on hydroelectric generation. This relationship is given formally by

$$
M E A N R_{t}=v(B) R A I N N A T_{t}
$$

Using the estimated coefficients (Table 3 ) it is written specifically

$$
\begin{gathered}
\text { MEANR }_{t}=896.22 \text { RAINNAT }_{t}-834.26 \text { RAINNAT }_{t-1}-526.13 \text { RAINNAT }_{t-2} \\
-262.03 \text { RAINNAT }_{t-8}-171.29 \text { RAINNAT }_{t-9}
\end{gathered}
$$

The variance of the estimated mean of the changes in precipitation is given by

$$
\operatorname{VARR}_{t}=\left(140.39 \text { RAINNAT }^{2}+\left(145.49 \text { RAINNAT }_{t-1}\right)^{2}+\left(139.87 \text { RAINNAT }_{t-2}\right)^{2}\right.
$$

${ }^{4}$ For more information, see: Sas Institute Inc., SAS/ETS User's Guide, Version 6 (Cary, NC, January 1989). 
$+\left(130.23 \text { RAINNAT } t_{t-8}\right)^{2}+\left(131.45 \text { RAINNAT }_{t-9}\right)^{2}$.

where the approximate standard errors of the estimated coefficients come from Table 3.

Table 3. ARIMA Output Containing Estimated Dummy Variable and Precipitation Lag Parameters

\begin{tabular}{|c|c|c|c|c|c|c|c|c|c|}
\hline \multicolumn{10}{|c|}{ Approximate } \\
\hline Parameter & \multicolumn{2}{|l|}{ Estimate } & Std. Error & T Ratio & Lag & \multicolumn{4}{|c|}{ Variable Shift } \\
\hline$M A 1,1 \ldots \ldots$ & \multicolumn{2}{|l|}{-0.29039} & 0.07168 & -4.05 & 13 & & NATIONAL & & 0 \\
\hline$M A 2,1 \ldots \ldots$ & \multicolumn{2}{|l|}{-0.13117} & 0.07594 & -1.73 & 12 & & NATIONAL & & 0 \\
\hline AR $1,1 \ldots \ldots$ & \multicolumn{2}{|l|}{0.85116} & 0.03234 & 26.32 & 1 & & NATIONAL & & 0 \\
\hline AR $1,2 \ldots$ & \multicolumn{2}{|l|}{-0.09212} & 0.04206 & -2.19 & 11 & & NATIONAL & & 0 \\
\hline NUM1 ..... & \multicolumn{2}{|l|}{896.22200} & 140.38903 & 6.38 & 0 & & RAINNAT & & 0 \\
\hline NUM1,1 ... & \multicolumn{2}{|l|}{-634.25619} & 145.49253 & -5.73 & 1 & & RAINNAT & & 0 \\
\hline NUM $1,2 \ldots$ & \multicolumn{2}{|l|}{$-\$ 26.13090$} & 139.86515 & -3.76 & 2 & & RAINNAT & & 0 \\
\hline NUM1,3 ... & \multicolumn{2}{|l|}{-262.02553} & 130.23461 & -2.01 & 8 & & RAINNAT & & 0 \\
\hline NUM1, $6 \ldots$ & \multicolumn{2}{|l|}{-171.28614} & 131.44949 & -1.30 & 9 & & RAINNAT & & 0 \\
\hline NUM2 ..... & \multicolumn{2}{|l|}{595.29831} & 35.24633 & 16.89 & 0 & & DUM1 & & 0 \\
\hline NUM3 ..... & \multicolumn{2}{|l|}{600.13781} & 35.31950 & 16.99 & 0 & & DUM2 & & 0 \\
\hline NUM4 . .... & \multicolumn{2}{|l|}{605.04081} & 35.52695 & 17.03 & 0 & & DUM3 & & 0 \\
\hline NUM5 ..... & \multicolumn{2}{|l|}{600.80657} & 36.09334 & 16.65 & 0 & & DUM4 & & 0 \\
\hline NUM6 ..... & \multicolumn{2}{|l|}{610.64743} & 38.26016 & 15.96 & 0 & & DUM5 & & 0 \\
\hline NUM7 ..... & \multicolumn{2}{|l|}{589.90960} & 38.65004 & 15.26 & 0 & & DUM6 & & 0 \\
\hline NUMB . .... & \multicolumn{2}{|l|}{511.49184} & 39.02628 & 13.11 & 0 & & DUM7 & & 0 \\
\hline NUM9 . .... & \multicolumn{2}{|l|}{453.11518} & 38.12019 & 11.89 & 0 & & DUM8 & & 0 \\
\hline NUM10 .... & \multicolumn{2}{|l|}{404.01621} & 37.03964 & 10.91 & 0 & & DUM9 & & 0 \\
\hline NUM11 .... & \multicolumn{2}{|l|}{404.01113} & 35.34626 & 11.43 & 0 & & DUM10 & & 0 \\
\hline NUM12 .... & \multicolumn{2}{|l|}{476.45024} & 35.54321 & 13.46 & 0 & & DUM11 & & 0 \\
\hline NUM13 .... & \multicolumn{2}{|l|}{560.71792} & 35.08532 & 15.98 & 0 & & DUM12 & & 0 \\
\hline \multicolumn{2}{|c|}{ Variance Estimate } & $=$ & 1688.87656 & & & & & & \\
\hline \multicolumn{2}{|c|}{ Std. Error Estimate } & $=$ & 41.0959434 & & & & & & \\
\hline AIC & & $=$ & 2764.43375 & & & & & & \\
\hline $\mathrm{SBC}$ & & $=$ & 2839.76597 & & & & & & \\
\hline Number of $R \epsilon$ & siduals & $=$ & 267 & & & & & & \\
\hline Lag & Chi Square & DF & Prob & & & Autoce & orrelations & & \\
\hline 6 & 4.31 & 2 & 0.116 & 0.029 & -0.002 & -0.058 & 0.029 & 0.060 & 0.084 \\
\hline 12 & 7.77 & 8 & 0.456 & 0.030 & 0.001 & -0.066 & 0.025 & -0.078 & 0.018 \\
\hline 18 & 14.07 & 14 & 0.444 & 0.018 & 0.080 & -0.099 & -0.054 & 0.010 & 0.049 \\
\hline 24 & 20.55 & 20 & 0.424 & 0.043 & 0.024 & 0.074 & -0.005 & -0.011 & 0.118 \\
\hline 30 & 22.18 & 26 & 0.679 & -0.032 & 0.041 & -0.004 & -0.030 & -0.037 & 0.022 \\
\hline 36 & 27.30 & 32 & 0.703 & -0.004 & 0.065 & -0.017 & -0.023 & -0.085 & -0.065 \\
\hline 42 & 36.22 & 38 & 0.552 & 0.010 & -0.093 & -0.011 & -0.136 & -0.009 & -0.028 \\
\hline
\end{tabular}

For purposes of forecasting generation, these two mean functions are subtracted from the past generation data, the autoregressive and moving average parts of the model (Table 3) are reestimated, and used to forecast 18 to 27 months ahead. MEANS, the seasonal effects on the generation, is calculated for the forecasts using the known dummy variables 
each representing a month. MEANR, the impact of precipitation on the generation, is calculated for the forecasts using the actual precipitation for past months which are still affecting generation in the forecast period and an estimated "normal" monthly precipitation as the monthly forecasts. ${ }^{5}$ These impacts are then added to the forecasts from ARIMA. The estimated forecast variance from ARIMA is added to VARS $S_{t}$ and VARR, the variances of the estimated seasonal and precipitation effects, and is used to calculate 95 percent confidence intervals for the forecasts.

The autoregressive part of the model using coefficients given by AR (Table 3 ) is

$$
\Phi(B)=\left(1-0.85 B+0.09 B^{11}\right)
$$

The moving average part of the model using coefficients given by MA (Table 3) is

$$
\theta(B)=\left(1+0.29 B^{13}\right)\left(1+0.13 B^{12}\right)
$$

After specifying the model for the ARIMA procedure, the procedure automatically makes use of these formulas in calculating the forecasts.

Detailed output from the model is available upon request.

\section{Regional Models}

The national model described above was used for several years as input for the STEO. However, regional models were needed for the STEO. Therefore, models were developed by region using the same methodology used in determining the national model as described above. The regional models replace the national model, with the sum of all regional models becoming the forecast for the Nation as a whole. Table 4 contains a summary of the parameters chosen for each regional model. Appendix $\mathrm{E}$ contains the estimated dummy variable and precipitation lag parameters for all the regional models.

\begin{tabular}{|c|c|c|c|}
\hline & $\begin{array}{c}\text { Moving Average } \\
\text { Parameters }\end{array}$ & $\begin{array}{c}\text { Autoregressive } \\
\text { Parameters }\end{array}$ & Rain Lags \\
\hline Region 1 . & None & $(1,9)$ & $(1,2,3,4,5,7)$ \\
\hline Region $2 \ldots$ & (1) & $(1,8)$ & $(1,2,3,4,5,8,9)$ \\
\hline Region $3 . .$. & None & $(1,5)$ & $(1,2,3,4,6)$ \\
\hline Region $4 \ldots$ & $(11)(12)$ & $(1,8)$ & $(9,10,13,14)$ \\
\hline Region $5 \ldots$ & None & $(1,3,7)$ & $(1,2,3,4,5,6,7)$ \\
\hline Region 6 . & None & $(1,2)$ & $(1,2,3,4,5,7)$ \\
\hline Region $7 \ldots \ldots \ldots \ldots \ldots \ldots$ & (11) & $(1,7,17)$ & $(1,2,3,4,5,7)$ \\
\hline Region 8 . & (2) & (1) & $(1,2,3,4,10,11)$ \\
\hline Region 9. & $(1,4,8,15,17)(12,13)$ & $(1,9)$ & $(1,2,3,5,9)$ \\
\hline
\end{tabular}

Table 4. Regional Model Parameters

${ }^{5}$ Monthly averages of precipitation data from 1970 to the present are used as "normal" precipitation. 


\section{Properties of the Mathematical Solution}

\section{Theoretical Considerations}

See Assumptions, Alternative Approaches, and List of Computations and Equations.

\section{Subject-Matter Considerations}

Because the hydroelectric generation data exhibit seasonality, the STHGM uses dummy variables each representing a month to account for seasonality. Seasonality needs to be accounted for in the raw data in order for the time series model to reflect it in the forecasts.

Precipitation is an explanatory variable to the time series model because of the dependency of hydroelectric generation on precipitation historically. Precipitation levels determine the availability of water in reservoirs for electricity generation, as well as the effects of recent rain or snow on run-of-river hydroelectric facilities. Average precipitation is used during the forecast period for hydroelectric generation which is consistent with the assumption of normal weather for the STEO forecasts.

\section{Calibration and Sensitivity Analysis}

\section{Results of Calibration}

Evaluation of the model was performed using out-of-sample tests. That is, several different periods of actual data were deleted from the input data, the parameters in the model were reestimated, and forecasts made as described above for a 24-month period. These forecasts were compared to actual data and past forecasts for the Short-Term Energy Outlook based on the same historical data.

\section{National Model}

The first comparison was to graph the out-of-sample results (Figures 2, 3, and 4). . From the graphs, the following conclusions are illustrated: (1) the STHGM forecast is in general closer to the actual generation than the previous STEO forecasts; (2) the 1990 and 1991 actual data are close to the long run average hydroelectric generation and the STHGM forecasts for these years is generally within 1 to 2 billion kilowatthours of the actual generation; (3) for 1992, an unusually low year for hydroelectric generation, both forecasts are not as good as for 1990 and 1991, which can be explained by the forecast assumption of normal precipitation and the fact that precipitation was below normal in 1992; (4) in 1992, with the below normal hydroelectric generation, the STHGM still provides a closer forecast than used in the STEO; and (5) as the input data gets closer to 1992, the STHGM forecasts improved for 1992.

The second comparison was with the Root Mean Square Errors (RMSE) of the model runs (Table 4), where $n$ is the number of months of the forecast included in the calculation and

$$
\text { RMSE }=\sqrt{\sum_{i=1}^{n} \frac{\left(\text { FORECAST }_{i}-A C T U A L_{i}\right)^{2}}{n}} .
$$

In all cases the RMSE of the STHGM is smaller than the RMSE of the STEO forecasts. The RMSEs show the improvement of both forecasts for a particular year as the input data gets closer to that year.

\section{Regional Models}

As for the national STHGM, out-of-sample tests were performed for the regional STHGM (Figures 5, 6, 7, and 8). Precipitation data for the out-of-sample tests was lagged 6 months behind the generation data as this is the normal occurrence. From the graphs, the following conclusions are illustrated: (1) the regional STHGM forecast based on actual 
data through 1992 provides a closer national forecast than the methodology used in the STEO at the time, that is, the premodel methodology described earlier in this documentation; (2) the regional STHGM forecast and the STEO forecast (national STHGM model) based on actual data through 1993 provide very similar forecasts; (3) looking individually at two of the regional forecasts, the regional STHGM provides closer regional forecasts than the methodology previously used to determine regional forecasts. ${ }^{6}$

The second comparison was again the RMSE of the model runs and previous STEO forecasts (Table 5). In only one instance is the RMSE greater for the STHGM; however, that is only the case for the national total--both regional forecasts have a lower RMSE in that sample.

\section{Correlation Concerns}

One further concern involves the correlation of the dummy variables and the precipitation variables. Correlation is not taken into account when the two mean functions are subtracted from the past generation data, nor is it taken into account in the forecast. However, correlation among the dummy variables is always 0 , because only one of the variables is nonzero for any one observation. The precipitation variables do have correlation, but it is not large enough to be of concern. Therefore, the model remains acceptable with no correction for correlation among the explanatory variables.

\footnotetext{
${ }^{6}$ The previous methodology used to determine regional forecasts of hydroelectric generation was based on the output from the national STHGM. Regional splits of the national yearly forecasted generation were determined based on previous years' splits and knowledge of the current year's increase or decrease from normal levels of generation in each region. These regional totals were used along with the monthly national level generation forecast from the STHGM to proportionally determine monthly regional levels of generation.
} 
Figure 2. Out of Sample and STEO Forecasts Using Actual Data through 1989 Compared to Actual Data, 1990 and 1991

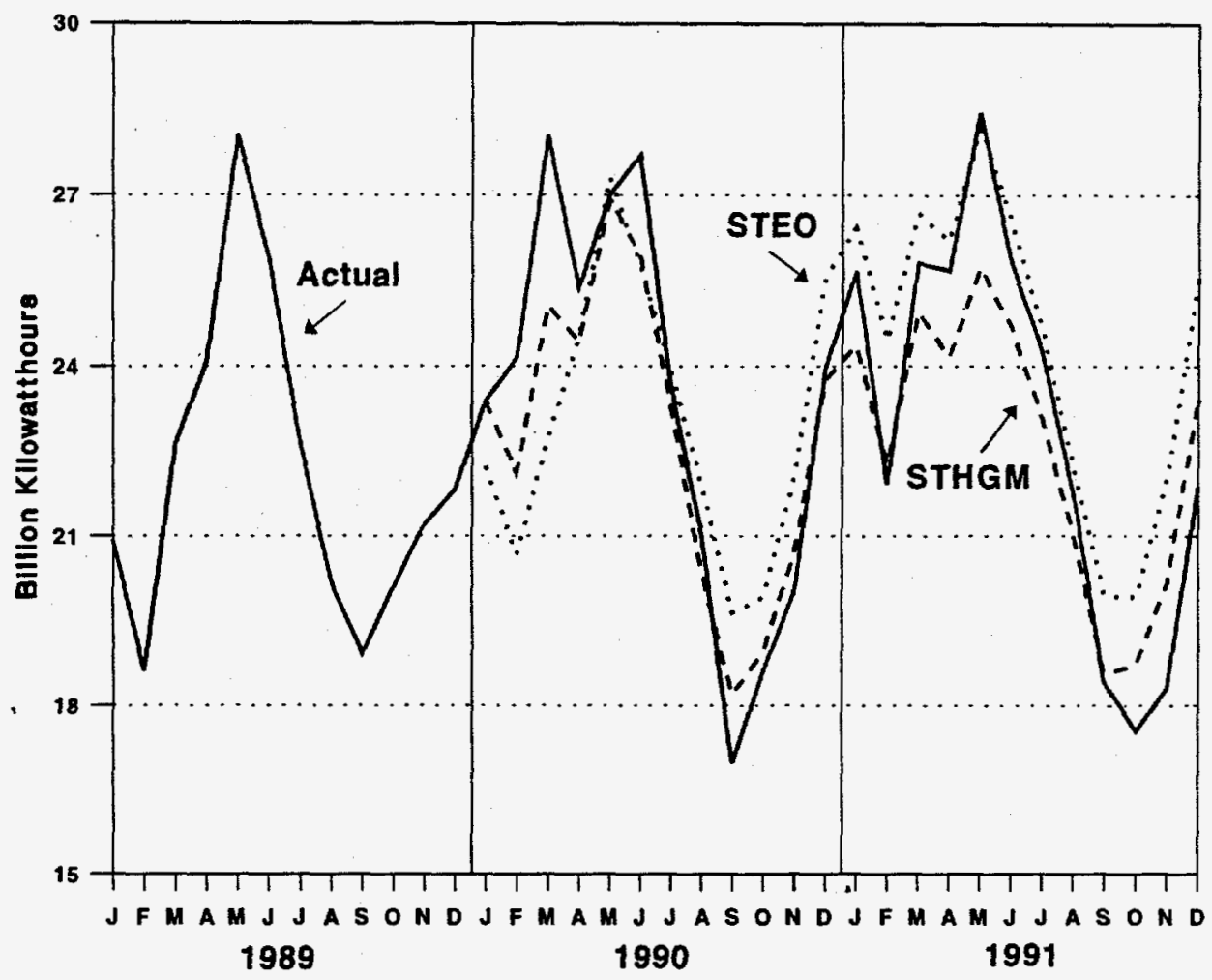

Notes: -All forecasts are based on actual generation and precipitation data through the indicated year. $\bullet$ All forecasts assume nomal precipitation during the forecast period. Data shown in Table C1.

Source: STEO Forecasts: Energy Information Administration, Office of Coal, Nuclear, Electric, and Alternate Fuels memo to Office of Energy Markets and End Use dated March 13, 1990. STHGM Forecasts: Energy Information Administration, STHGM nu using HYDRO.TIME.SERIES.FINAL.D060193. Actual: Energy Information Administration, Form ElA-759, "Monthly Power Plant Report." 
Figure 3. Out of Sample and STEO Forecasts Using Actual Data through 1990 Compared to Actual Data, 1991 and 1992

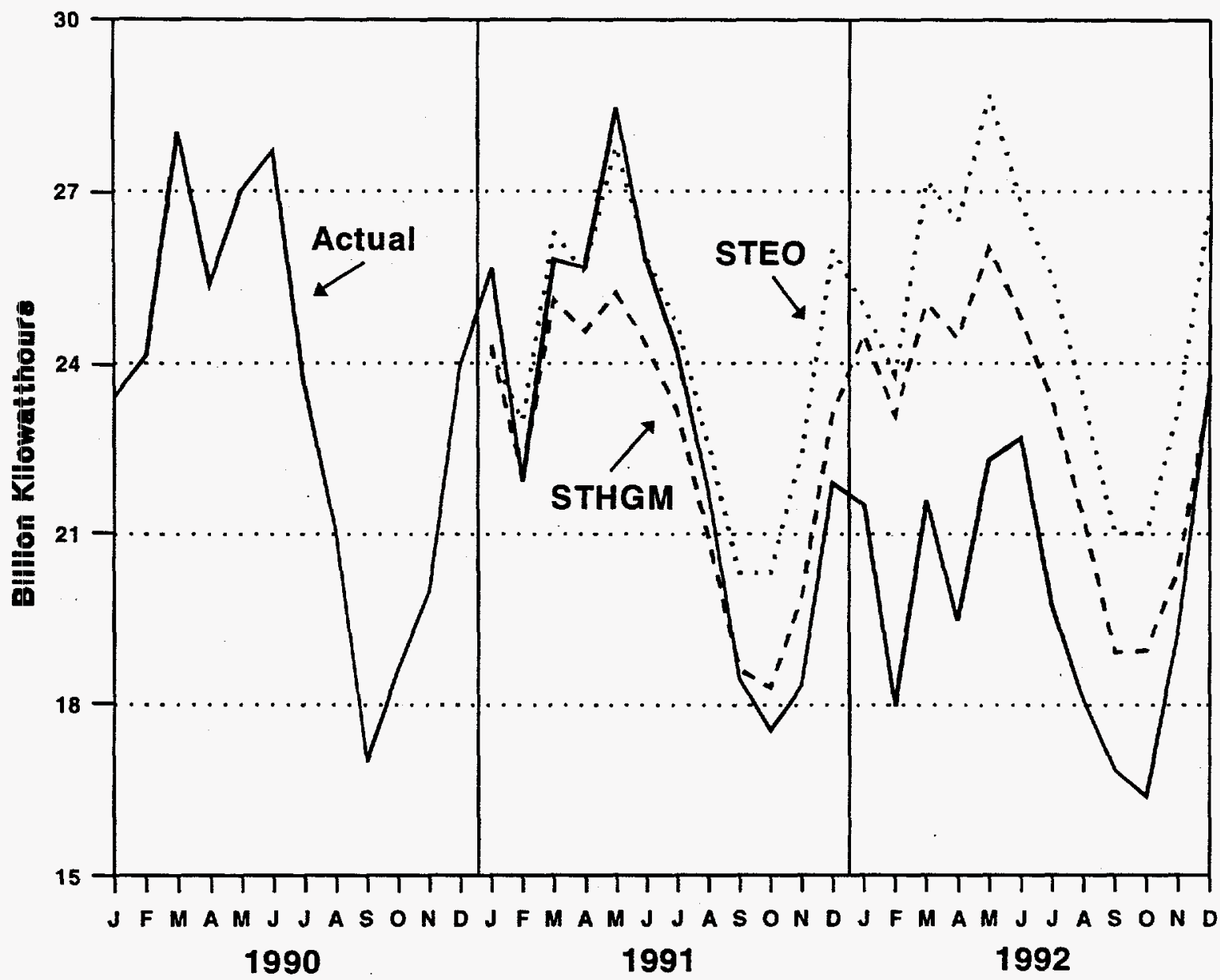

Notes: All forecasts are based on actual generation and precipitation data through the indicated year. All forecasts assume normal precipitatior during the forecast period. $\bullet$ Data shown in Table C2.

Source: STEO Forecasts: Energy Information Administration, Office of Coal, Nuclear, Electric, and Alternate Fuels memo to Office of Energy Markets and End Use dated March 19, 1991. STHGM Forecasts: Energy Information Administration, STHGM run using HYDRO.TIME.SERIES.FINAL.D060193 Actual: Energy Information Administration, Form ElA-759, "Monthly Power Plant Report." 
Figure 4. Out of Sample and STEO Forecasts Using Actual Data through 1991 Compared to Actual Data, 1992 and 1993

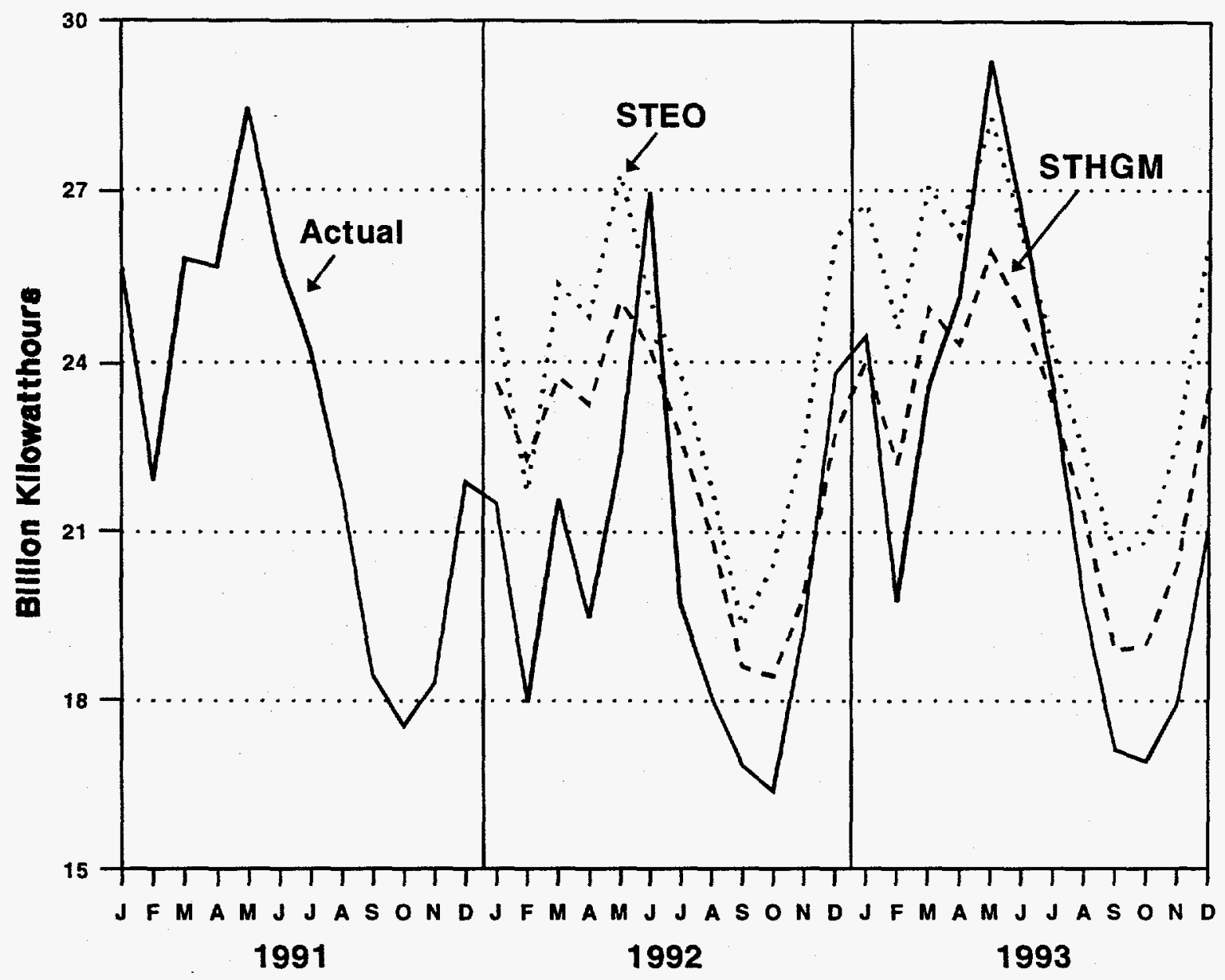

Notes: -All forecasts are based on actual generation and precipitation data through the indicated year. $\bullet$ All forecasts assume normal precipitation during the forecast period. - Data shown in Table C3.

Source: STEO Forecasts: Energy Information Administration, Office of Coal, Nuclear, Electric, and Altemate Fuels memo to Office of Energy Markets and End Use dated March 6, 1992. STHGM Forecasts: Energy Information Administration, STHGM run using HYDRO.TIME.SERIES.FINAL.D060193. Actual: Energy Information Administration, Form ElA-759, "Monthly Power Plant Report." 
Figure 5. Out of Sample (Regional STHGM) and STEO Forecasts Using Actual

Generation Data through 1992 Compared to Actual Data, 1993 and 1994

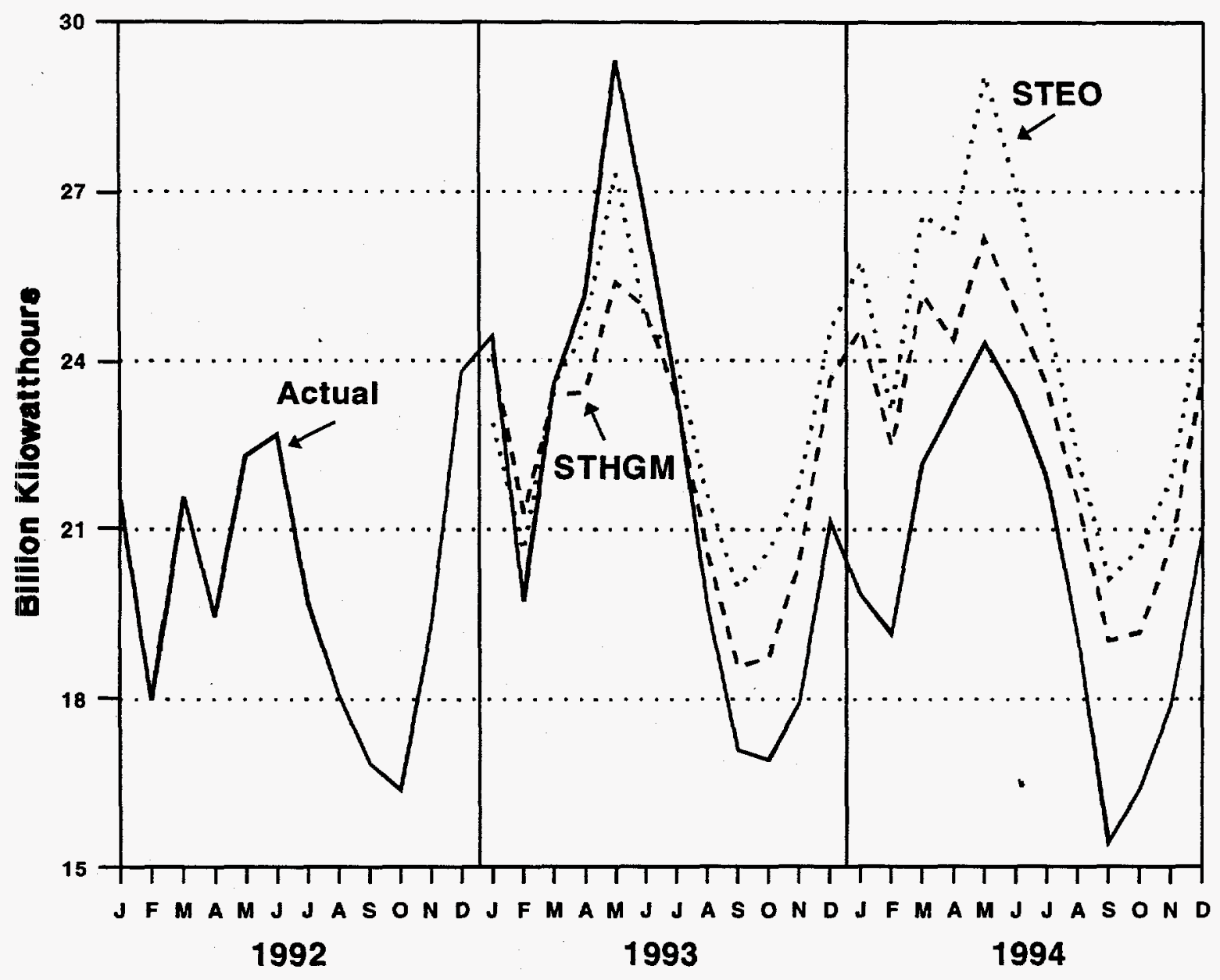

Notes: $\bullet$ All forecasts are based on actual generation data through 1992 and precipitation data through June of 1992 . $\bullet$ All forecasts assume normal precipitation after the last month of available actual data. Data shown in Table C4.

Source: STEO Forecasts: Energy Information Administration, Office of Coal, Nuclear, Electric, and Alternate Fuels memo to Office of Energy Markets and End Use dated March 8, 1993. STHGM Forecasts: Energy Information Administration, STHGM run using HYDRO.MODEL. Actual: Energy Information Administration, Form ElA-759, "Monthly Power Plant Report." 
Figure 6. Out of Sample (Regional STHGM) and STEO Forecasts Using Actual Generation Data through 1993 Compared to Actual Data, 1994 and 1995

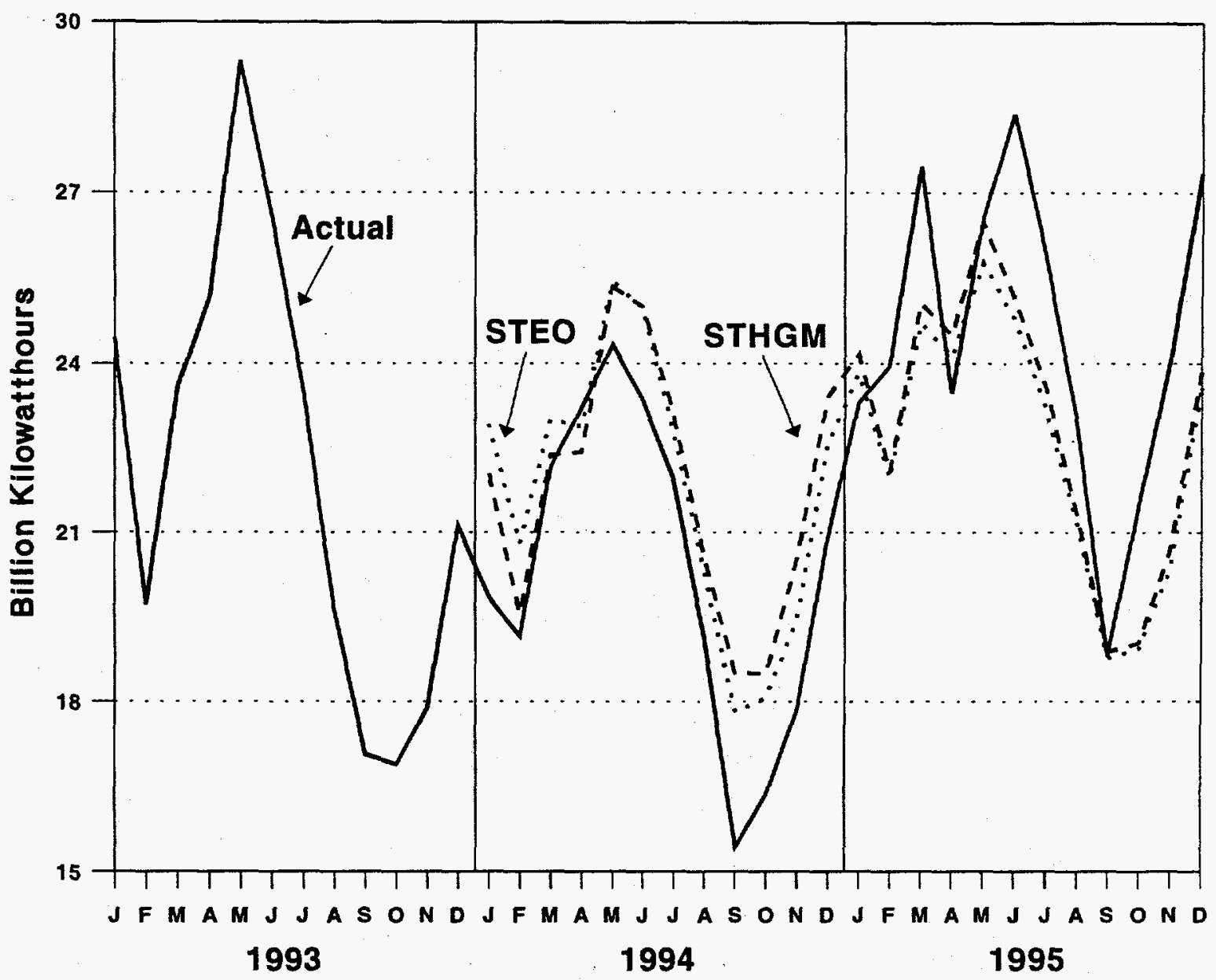

Notes: •All forecasts are based on actual generation data through 1993 and precipitation data through June of 1993. •All forecasts assume normal precipitation after the last month of available actual data. $\bullet$ Data shown in Table C5.

Source: STEO Forecasts: Energy Information Administration, Office of Coal, Nuclear, Electric, and Alternate Fuels memo to Office of Energy Markets and End Use dated March 7, 1994. STHGM Forecasts: Energy Information Administration, STHGM run using HYDRO.MODEL. Actual: Energy Information Administration, Form EIA-759, "Monthly Power Plant Report." 
Figure 7. Out of Sample (Regional STHGM) and STEO Forecasts for Region 9 (Using Actual Generation Data through 1993 Compared to Actual Data, 1994 and 1995

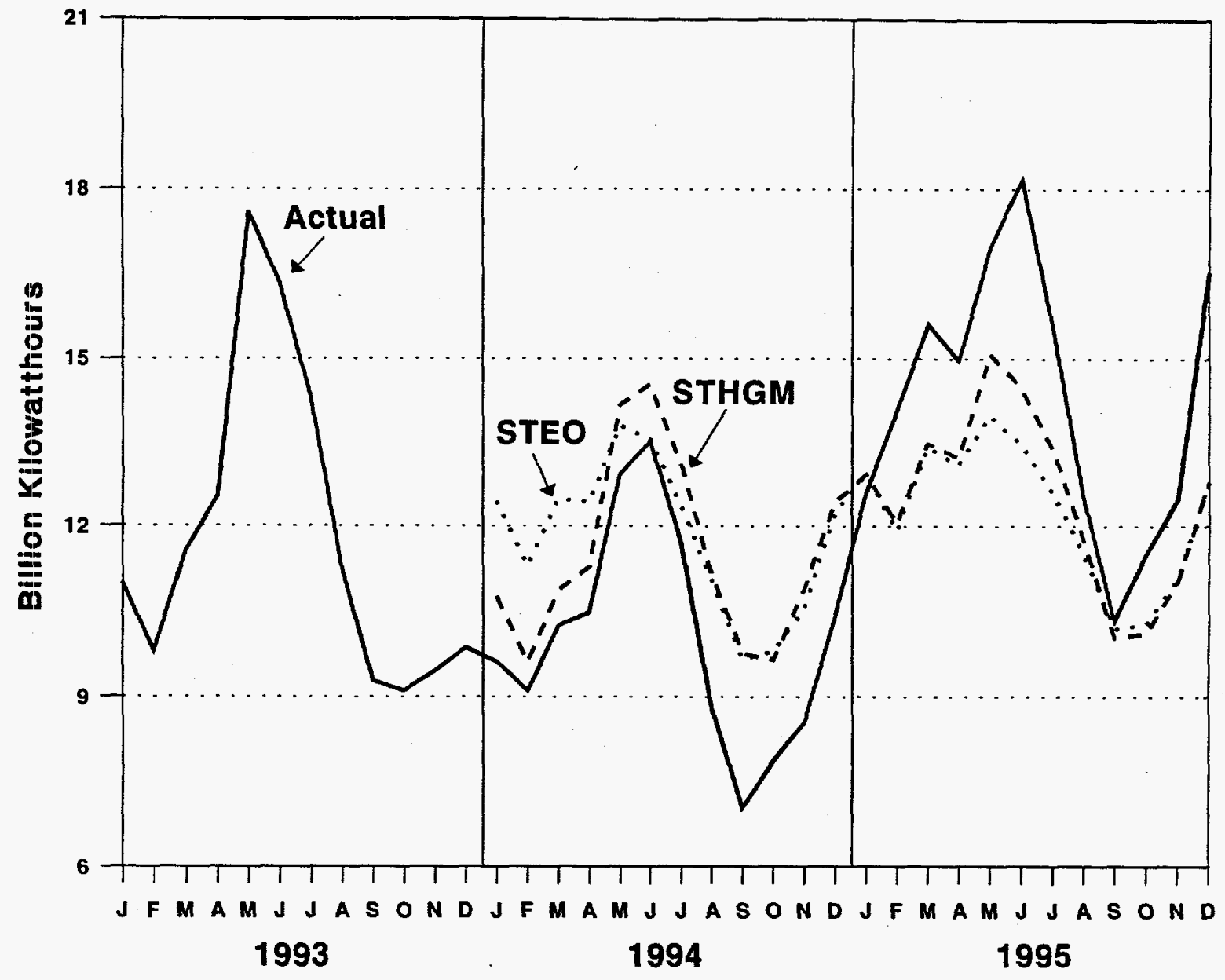

Notes: -All forecasts are based on actual generation data through 1993 and precipitation data through June of 1993. •All forecasts assume normal . precipitation after the last month of available actual data. -Data shown in Table C6.

Source: STEO Forecasts: Energy Information Administration, Office of Coal, Nuclear, Electric, and Alternate Fuels memo to Office of Energy Markets and End Use dated March 7, 1994. STHGM Forecasts: Energy Information Administration, STHGM run using HYDRO.MODEL. Actual: Energy Information Administration, Form ElA-759, "Monthly Power Plant Report." 
Figure 8. Out of Sample (Regional STHGM) and STEO Forecasts for Region 5 (Using Actual Generation Data through 1993 Compared to Actual Data, 1994 and 1995

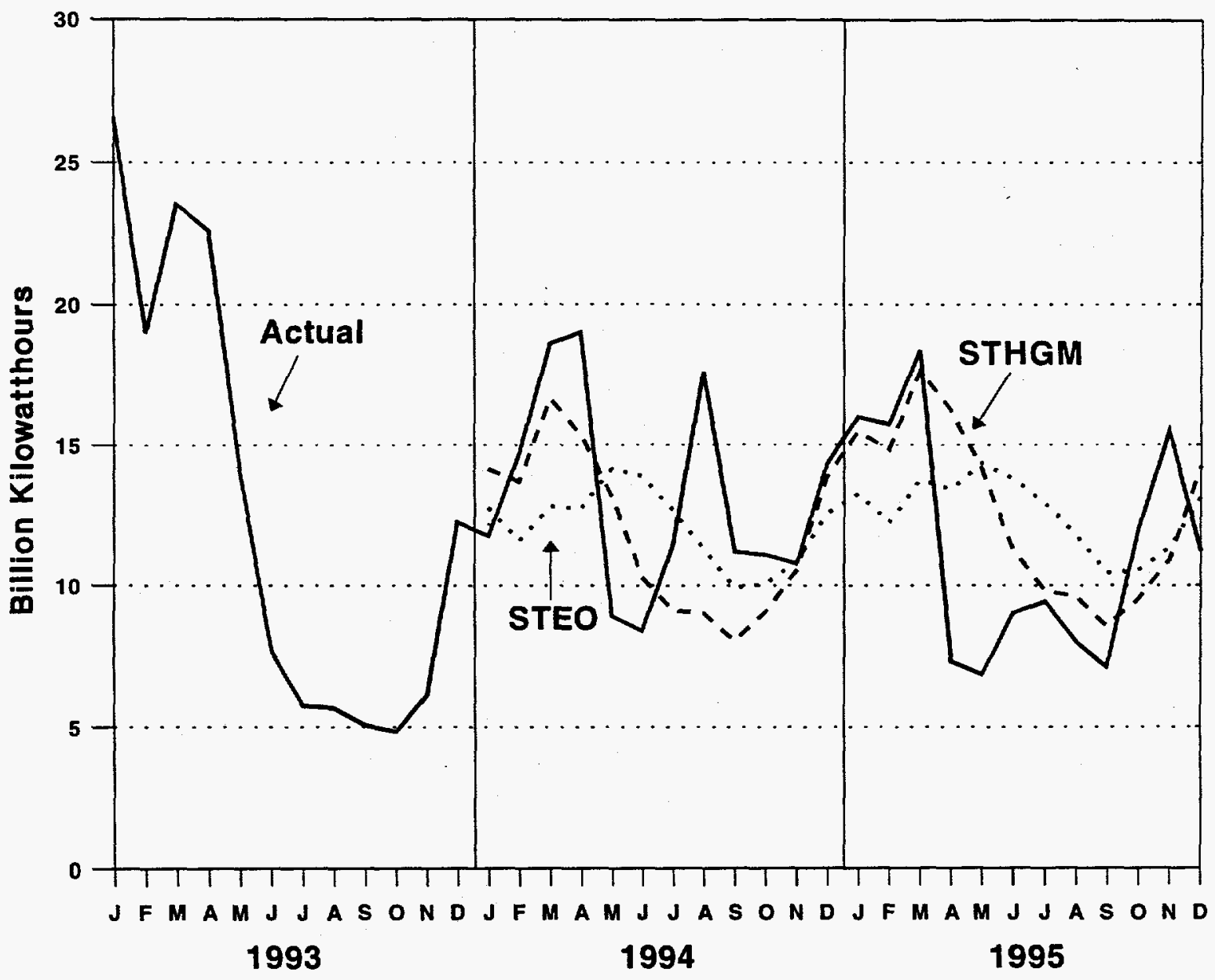

Notes: -All forecasts are based on actual generation data through 1993 and precipitation data through June of 1993 . All forecasts assume normal precipitation after the last month of available actual data. Data shown in Table C6.

Source: STEO Forecasts: Energy Information Administration, Office of Coal, Nuclear, Electric, and Alternate Fuels memo to Office of Energy Markets and End Use dated March 7, 1994. STHGM Forecasts: Energy Information Administration, STHGM run using HYDRO.MODEL. Actual: Energy Information Administration, Form ElA-759, "Monthly Power Plant Report." 
Table 5. Comparison of Root Mean Square Errors for Regional STHGM

\begin{tabular}{|c|c|c|c|c|c|c|c|}
\hline \multirow{2}{*}{$\begin{array}{r}\text { Using } \\
\text { Historical } \\
\text { Data } \\
\text { through: }\end{array}$} & \multirow{2}{*}{$\begin{array}{c}\text { Year(s) of } \\
\text { Forecast } \\
\text { Included in the } \\
\text { RMSE }\end{array}$} & \multicolumn{2}{|c|}{ RMSE: National } & \multicolumn{2}{|c|}{ RMSE: Region 9} & \multicolumn{2}{|c|}{ RMSE: Region 5} \\
\hline & & STHGM & STEO & STHGM & STEO & STHGM & STEO \\
\hline \multirow[t]{3}{*}{ 1992: } & 1993 & 1,887 & 2,293 & 1,632 & 1,925 & 538 & 770 \\
\hline & 1994 & 2,881 & 4,160 & 2,784 & 3,183 & 354 & 403 \\
\hline & 1993 and 1994 & 2,400 & 3,358 & 2,282 & 2,630 & 455 & 615 \\
\hline \multirow[t]{3}{*}{ 1993: } & 1994 & 1,830 & 1,654 & 1,650 & 1,950 & 340 & 396 \\
\hline & 1995 & 2,218 & 2,426 & 2,097 & 2,445 & 388 & 428 \\
\hline & 1994 and 1995 & 2,033 & 2,077 & 1,887 & 2,212 & 365 & 412 \\
\hline
\end{tabular}

Notes: $\bullet$ All forecasts are based on actual generation data through the indicated year and actual precipitation data through 6 months prior to the indicated years. All forecasts assume normal precipitation after the last month of avallable actual data.

Source: STEO Forecasts: Energy Information Administration, Office of Coal, Nuclear, Electric, and Altemate Fuels memos to Office of Energy Markets and End Use dated March 8, 1993, March 7, 1994, and March 6, 1992. STHGM Forecasts: Energy Information Administration, STHGM runs using HYDRO.MODEL. 


\section{Documentation of Technical Detail on the Model Data and Equations}

\section{Description of Input Data}

Input hydroelectric generation data for the STHGM is from archived databases of the Form EIA-759, "Monthly Power Plant Report," from 1970 through 1992. Data prior to 1978 may differ from published data due to unreturned forms that were estimated in the published data. The differences in the published data and the database is generally less than 0.1 percent; and, therefore, the database was used.

Once the model has read in the generation data, the data are divided by the number of days in each month in order to account for the different lengths of the months. Once the time series procedure is completed, the forecast of average daily generation is multiplied by the number of days in each month to produce estimates of monthly generation.

The monthly input precipitation data from 1970 to 1992 and the 57-year average precipitation data are from the National Climatic Data Center. These numbers were hand typed into the needed format. Forecasted precipitation data are the monthly averages for the 57-year period from 1931 to 1987 from the National Climatic Data Center. ${ }^{7}$ The precipitation data, like the generation data, was adjusted to account for the number of days in the month.

\section{Non-DOE Input Sources}

- 1970-1992: National Climatic Data Center (NCDC), Disc. Resident Historical Divisional DataBase (DRD964X). These data are weighted by population using State and regional weights from the NCDC's State, Regional, and National Monthly and Annual Precipitation Weighted by Area for the Contiguous United States January 1931 - December 1987 (Asheville, NC, August 1988). The calculated data differ slightly from the published data due to updates of the State and regional weights. 1993-present: National Climatic Data Center, Monthly State, Regional and National Heating Degree Days Weighted by Population (Asheville, NC, March, 1989 through present), Table 3.3, "Regional and National Average Precipitation." These data are updated each time the model is run. Data are published weighted by population.

- Regional precipitation data.

\section{DOE Data Input Sources}

- Energy Information Administration, Databases for Form ElA-759, "Monthly Power Plant Report," and predecessors.

- Hydroelectric generation data.

\section{ARIMA Output Providing Coefficient Estimates}

The coefficient estimates and a number of statistics related to the goodness-of-fit of the equations estimated by the STHGM are listed in Appendix E.

\footnotetext{
'National Climatic Data Center, State, Regional, and National Monthly and Annual Precipitation Weighted by Area for the Contiguous United States January 1931 - December 1987 (Asheville, NC, August 1988), p. 66.
} 


\section{Appendix A. Model Abstract}

Modell Name: Short-Term Hydroelectric Generation Model

Model Acronym: STHGM

Model Description: The STHGM performs a short-term (18 to 27-month) forecast of hydroelectric generation in the United States by Census Division using an autoregressive integrated moving average (ARIMA) time series model with precipitation as an explanatory variable. The model results are used as input for the Short-Term Energy Outlook.

Last Model Update: March 1995

Part of Another Model: None.

Model Interfaces: None. Results used as independent input into the Short-Term Integrated Forecasting System (STIFS).

Sponsor:

- Office: Office of Coal, Nuclear, Electric and Alternate Fuels.

- Division: Analysis and Systems Division.

- Branch: Supply Analysis Branch, EI-532.

- Model Contact: William Liggett.

- Telephone: 202-426-1139.

Documentation: Energy Information Administration, "Model Documentation Report: Short-Term Hydroelectric Generation Model."

Archive Media and Installation Guides: Archived on Energy Information Administration mainframe system under the name "HYDRO.FINAL" on account RMF6434. The model is written in SAS version 6.08 .

Purpose: The STHGM is to be used for general forecasting purposes to provide quarterly projections of monthly national and regional hydroelectric generation for the Short-Term Energy Outlook.

Energy Systems Described by Model: National and regional (Census Division) hydroelectric generation.

Coverage:

- Geographic: National and Census Division.

- Time Unit/Frequency: Monthly.

- Products: Hydroelectric Generation. 


\section{Modelling Features:}

- Model Structure: Autoregressive integrated moving average (ARIMA) time series model with an explanatory variable.

- $\quad$ Modelling Technique: Time series analysis.

- Special Features: None.

\section{Non-DOE Input Sources}

- 1970-1992: National Climatic Data Center (NCDC), Disc. Resident Historical Divisional DataBase (DRD964X). These data are weighted by population using State and regional weights from the NCDC's State, Regional, and National Monthly and Annual Precipitation Weighted by Area for the Contiguous United States January 1931 December 1987 (Asheville, NC, August 1988). The calculated data differ slightly from the published data due to updates of the State and regional weights. 1993-present: National Climatic Data Center, Monthly State, Regional and National Heating Degree Days Weighted by Population (Asheville, NC, March, 1989 through present), Table 3.3, "Regional and National Average Precipitation." These data are updated each time the model is run. Data are published weighted by population.

- Regional (Census Division) precipitation data.

\section{DOE Data Input Sources}

- Energy Information Administration, Databases for Form EIA-759, "Monthly Power Plant Report," and predecessors.

- Hydroelectric generation data.

General Output Descriptions: STHGM is used to generate short-term (18 to 27 -month), monthly forecasts of U.S. hydroelectric generation by Census Division.

\section{Computing Environment:}

- Hardware Used: Energy Information Administration Mainframe System (Model Number IBM 3090).

- Operating System: MVS.

- $\quad$ Software Used: SAS version 6.08 .

- $\quad$ Estimated Run Time: Approximately 1 minute computer time on EIA Mainframe System.

- Special Features: None.

Independent Expert Reviews: None.

Status of Evaluations by Sponsor: On-going.

Bibliography:

- $\quad$ George E. Box and Gwilym Jenkins, Time Series Analysis, Forecasting and Control (1976).

- Sas Institute Inc., SAS/ETS User's Guide, Version 6 (Cary, NC, January 1989). 


\section{Appendix B. Source Code}

Following is the complete source code for the STHGM. The model was written in SAS 6.08 and is run in a mainframe environment using SuperWylbur and JCL. A list of variable definitions follows the code.

/ /RR5UTMMD JOB $(6434$, HST, 80$)$, 'HYDRO.TIME',TIME $=(1,30)$

//STEP1 EXEC SAS,OPTIONS='MACRO',REGION=4024K,TIME= $=(1,30)$

//FORM1 DD DSN=CN6434.RR5.HYDRO.HISTORY.DATA.USE,

$/ / \quad$ DISP $=$ SHR, LABEL $=(,,, \mathbb{N})$

//PREC DD DSN=CN6434.RR5.PRECIP.USE,

$/ / \quad$ DISP $=$ SHR,LABEL $=(,,, \mathbb{N})$

$1 /{ }^{*}$

*OPTIONS MPRINT NONOTES NOSOURCE NOCENTER;

OPTIONS MPRINT NOCENTER;

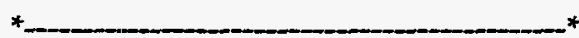

I THIS JOB PERFORMS A TIME SERIES FOR HYDRO |

*

${ }^{* * * * *}$ MACROS *****;

*- CALCULATE THE NUMBER OF DAYS IN EACH MONTH -..*;

$\%$ MACRO NUMDAYS;

IF MONTH < 12 THEN NEXTMON=MONTH+1; ELSE NEXTMON=1;

IF MONTH < 12 THEN NEXTYR=YR; ELSE NEXTYR=YR+1;

DAYS=MDY(NEXTMON,1,NEXTYR)-MDY(MONTH,1,YR);

DROP NEXTYR NEXTMON;

$\%$ MEND;

*- MULTTPLY THE FORECAST BY THE NUMBER OF DAYS IN EACH MONTH -*;

\%MACRO FOREDAYS;

DO I=1 TO 9;

$\mathrm{F}(\mathrm{I})=(\text { FORE }(\mathrm{I})+\mathrm{MEANS}(\mathrm{I})+\operatorname{MEANR}(\mathrm{I}))^{*} \mathrm{DAYS}$;

STDF $(\mathrm{I})=S \mathrm{SQRT}\left(\mathrm{STDEV}(\mathrm{I})^{* *} 2+\operatorname{VARS}(\mathrm{I})+\operatorname{VARR}(\mathrm{I})\right)^{*} \mathrm{DAYS}$;

$\mathrm{U} 95 \mathrm{CI}(\mathrm{I})=\mathrm{F}(\mathrm{I})+1.96 * \mathrm{STDF}(\mathrm{I})$;

$\mathrm{L} 95 \mathrm{CI}(\mathrm{I})=\mathrm{F}(\mathrm{I})-1.96^{*} \mathrm{STDF}(\mathrm{I})$;

END;

\%MEND;

*--- DROP UNNEEDED VARIABLES --*;

$\%$ MACRO DROP1;

DROP I1_1 I1_2 I1_3 I1_4 I1_5 I1_6 I1_7 I1_8 I2_1 I3_1 I4_1 I5_1

I6_1 I7_1 I8_1 19_1 I10_1 I11_1 I12_1 I13_1;

DROP S1_1 S1_2 S1_3 S1_4 S1_5 S1_6 S1_7 S1_8 S2_1 S3_1 S4_1 S5_1

\%MEND;

S6_1 S7_1 S8_1 S9_1 S10_1 S11_1 S12_1 S13_1; 
*-- CALCULATE YEAR \& MONTH OF FORECAST --..*;

\%MACRO YRCAL;

$\mathrm{C}=\_\mathrm{N}$;

$\mathrm{YR}=1900+(70+\mathrm{INT}((\mathrm{C}-.5) / 12))$;

MONTH=C $-(\text { YR-1970 })^{*} 12$;

\%MEND;

*-_- GET OUTPUT FROM ARIMA RUN IN USEABLE DATA FILE -...;

\%MACRO PARAMETR;

DATA EST1; SET ESTS;

IF_TYPE_='EST';

MERGEVAR $=1$;

DATA ONE; SET ONE;

MERGEVAR $=1$;

DATA ONE2;

MERGE ONE (IN=A) EST1;

BY MERGEVAR;

IF A;

DATA EST2; SET ESTS;

IF_TYPE_='STD';

MERGEVAR $=1$;

S1_1=I1_1;

S1_2=I1_2;

S1_3=I1_3;

S1_4=I1_4;

S1_5=I1_5;

S1_6=I1_6;

S1_7=I1_7;

S1_8=I1_8;

S2_1=I2_1;

S3_1=I3_1;

S4_1 $=14 \_1$;

S5_1=I5_1;

S6_1=I6_1;

S7_1=17_1;

S8_1=I8_1;

S9_1=19_1;

S10_1=I10_1;

S11_1=I11_1;

$\mathrm{S} 12 \_1=\mathrm{I12} \_$;

S13_1=I13_1;

DROP I1_1 I1_2 I1_3 I1_4 I1_5 I1_6 I1_7 I1_8 I2_1 I3_1 I4_1 I5_1

I6_1 17_1 18_1 I9_1 I10_1 I11_1 I12_1 I13_1;

DROP _TYPE_ERRORVAR MA1_1 MA1_2 MA1_3 MA1_4 MA1_5 MA2_1 MA2_2

AR1_1 AR1_2 AR1_3 AR1_4; 
DATA ONE3;

MERGE ONE2 (IN=A) EST2;

BY MERGEVAR;

DROP MERGEVAR;

IF A;

\%MEND;

**** READ IN GENERATION DATA ****;

DATA AA (DROP=REGION10);

INFILE FORM1;

ARRAY REGION( $\left.{ }^{*}\right)$ REGION1-REGION10;

INPUT YR 1-4 MONTH 9-10

@22 (REGION1-REGION10) (9.1);

DATE = MDY(MONTH,1,YR); FORMAT DATE MONYY;

REGION9=REGION9+REGION10;

IF $\mathrm{YR}>=70$ THEN YR=1900+YR;

$E L S E Y R=2000+Y R$;

DATA AA;

SET AA NOBS=NUM;

NUMAA=NUM;

**** READ IN PRECIPITATION DATA ****;

DATA RR;

INFILE PREC;

ARRAY RAIN $\left({ }^{*}\right)$ RAIN1-RAIN9;

INPUT YR 1-4 MONTH 9-10

$@ 22$ (RAIN1-RAIN9) (6.2);

DATE = MDY(MONTH,1,YR); FORMAT DATE MONYY.;

DATA RR;

SET RR NOBS=NUM;

NUMRR=NUM - 36;

**** MERGE DATASETS ***;

PROC SORT DATA $=A A$;

BY YR MONTH;

PROC SORT DATA=RR;

BY YR MONTH; 
DATA ONE;

MERGE AA (IN=A) RR ( $\mathbb{N}=\mathrm{B})$;

BY YR MONTH;

IF (A OR B) THEN OUTPUT;

*** ADJUST FOR \# OF DAYS PER MONTH ****;

DATA ONE (DROP=I DAYS);

SET ONE;

\%NUMDAYS

ARRAY REGION(*) REGION1-REGION9;

ARRAY RAIN( $\left.{ }^{*}\right)$ RAIN1-RAIN9;

DO I $=1$ TO 9;

REGION(I)=REGION(I)/DAYS;

RAIN(I)=RAIN $(\mathrm{I}) / D A Y S$;

END;

**** ESTABLISH DUMMY VARIABLES ****;

DATA ONE (DROP=I); SET ONE;

ARRAY DUM(*) DUM1-DUM12;

DO I=1 TO 12;

DUM(I)=0;

IF $M O N T H=I$ THEN DUM(I) $=1$;

END;

**** USE PORTION OF MERGED DATASET THAT INCLUDES ****

**** ACTUAL VALUES OF GENERATION AND PRECIPITATION ****;

DATA ONES; SET ONE;

IF _N_LE NUMRR;

**** FIRST ARIMA PROCUDURE ****;

**** COEFFECIENTS OF PARAMTERS USED FROM OUTPUT ****;

*??? REGION 9 ;

PROC ARIMA DATA=ONES;

IDENTIFY VAR=RAIN9 NLAG=24;

ESTIMATE $P=(1,7)(12) \mathrm{Q}=(11,12)$ ML PLOT;

TITLE1 'REGION 9: FIRST ARIMA';

IDENTIFY VAR=REGION9 CROSSCORR=(RAIN9 DUM1 DUM2 DUM3

DUM4 DUM5 DUM6 DUM7 DUM8 DUM9 DUM10 DUM11 DUM12) NLAG=22;

ESTTMATE $P=(1,9) Q=(1,4,8,15,17)(12,13)$ ML PLOT NOINT

INPUT $=((1,2,3,5,9)$ RAIN9 DUM1 DUM2

DUM3 DUM4 DUM5 DUM6 DUM7 DUM8 DUM9 DUM10 DUM11 DUM12)

OUTEST=ESTS; 
\%PARAMETR

**** ADJUST DATA FOR SEASONALITY AND PRECIPITATION CORRELATION **;

DATA NAT9; SET ONE3;

MEANS9=I2_1*DUM1+ I3_1*DUM2 + I4_1*DUM3 + I5_1* DUM4 + I6_1*DUM5+ I7_1*DUM6 + I8_1*DUM7+19_1* DUM8+

I10_1*DUM9+I11_1*DUM10+I12_1*DUM11+I13_1*DUM12;

MEANR9=I1_1*RAIN9-I1_2*LAG(RAIN9)-I1_3*LAG2(RAIN9)-

I1_4*LAG3(RAIN9)-I1_5*LAG5(RAIN9)-I1_6*LAG9(RAIN9);

VARS9 $=\left(\mathrm{S} 2 \_1 * 2\right)^{*} \mathrm{DUM} 1+\left(\mathrm{S} 3 \_1^{* * 2}\right)^{*} \mathrm{DUM} 2+\left(\mathrm{S} 4 \_1 * 2\right)^{*} \mathrm{DUM} 3+$

$\left(\mathrm{S} 5 \_1^{* * 2}\right)^{*}$ DUM4 + (S6_1*2)*DUM5 + (S7_1**2)*DUM6 +

$\left(\mathrm{S} 8 \_1 * 2\right)^{*}$ DUM7 + (S9_1**2)*DUM8 + (S10_1**2)*DUM9 +

$\left(\mathrm{S} 11 \_1^{* *} 2\right)^{*} \mathrm{DUM} 10+\left(\mathrm{S} 12 \_1^{* *}\right) * \mathrm{DUM} 11+\left(\mathrm{S} 13 \_1 * 2\right)^{*} \mathrm{DUM} 12$

VARR9 $=($ S1_ $1 * * 2) *($ RAIN9**2) +

$($ S1_2**2)*LAG(RAIN9)**2+

$(\text { S1_3**2)*LAG2(RAIN9) })^{* * 2}+$

$($ S1_4**2)*LAG3(RAIN9)**2 +

$($ S1_5**2)*LAG5(RAIN9)**2 +

$\left(\mathrm{S} 1 \_6 * 2\right)^{*}$ LAG9(RAIN9) ${ }^{* *}$;

\%DROP1

NEWNAT9=REGION9-MEANS9-MEANR9;

*??? REGION 8 ;

PROC ARIMA DATA=ONES;

IDENTIFY VAR=RAIN8 NLAG=24;

ESTTMATE $P=(1,2,5,17,19)(12)$ ML PLOT;

TITLE1 'REGION 8: FIRST ARIMA';

IDENTIFY VAR=REGION8 CROSSCORR=(RAIN8 DUM1 DUM2 DUM3

DUM4 DUM5 DUM6 DUM7 DUM8 DUM9 DUM10 DUM11 DUM12) NLAG=22;

ESTIMATE $\mathrm{P}=(1) \mathrm{Q}=(2)$ ML PLOT NOINT

INPUT $=((1,2,3,4,10,11)$ RAIN8 DUM1 DUM2

DUM3 DUM4 DUM5 DUM6 DUM7 DUM8 DUM9 DUM10 DUM11 DUM12)

OUTEST=ESTS;

\%PARAMETR

**** ADJUST DATA FOR SEASONALITY AND PRECIPITATION CORRELATION **;

DATA NAT8; SET ONE3;

MEANS8 $=12 \_1 *$ DUM1 + I3_1*DUM2 + I4_1*DUM3 + I5_1* DUM4 + I6_1*DUM5+ 17_1*DUM6 +18_1*DUM7+19_1* DUM8+

I10_1*DUM9+I11_1*DUM10+I12_1*DUM11+I13_1*DUM12;

MEANR8=I1_1*RAIN8-I1_2*LAG(RAIN8)-11_3*LAG2(RAIN8)-

I1_4*LAG3(RAIN8)-I1_5*LAG4(RAIN8)-I1_6*LAG10(RAIN8)-

I1_7*LAG11(RAIN8); 
VARS8 $=\left(\right.$ S2_1**2)*DUM1 $+\left(\text { S3_ } 1{ }^{* * 2}\right)^{*}$ DUM2 $+($ S4_1**2)*DUM3 + $(\text { S5_1 } 1 * 2)^{*}$ DUM4 + (S6_1**2)*DUM5 + (S7_1*2)*DUM6 + $($ S8_1**2)*DUM7 + (S9_1**2)*DUM8 + (S10_1*2)*DUM9 + $\left(\mathrm{S} 11 \_1^{* * 2}\right)^{*} \mathrm{DUM} 10+\left(\mathrm{S} 12 \_1^{* * 2}\right)^{*} \mathrm{DUM} 11+\left(\mathrm{S} 13 \_1^{* *} 2\right)^{*} \mathrm{DUM} 12$;

VARR8 $=\left(\mathrm{S} 1 \_1 * * 2\right)^{*}\left(\right.$ RAIN8 $\left.{ }^{* * 2}\right)+$ $($ S1_2**2)*LAG(RAIN8)**2 + $($ S1_3**2)*LAG2(RAIN8)**2 + $\left(\text { S1_4 }{ }^{* *} 2\right)^{*}$ LAG3(RAIN8)**2 + $\left(\mathrm{S} 15^{* * 2}\right)^{*}$ LAG4(RAIN8)**2 + $\left(\mathrm{S} 16^{* * 2}\right)^{*}$ LAG10(RAIN8)**2 + $\left(\mathrm{S} 17^{* * 2}\right)^{*}$ LAG11(RAIN8) ${ }^{* * 2}$;

$\%$ DROP1

NEWNAT8=REGION8-MEANS8-MEANR8;

*?? REGION 7 ;

PROC ARIMA DATA=ONES;

IDENTIFY VAR=RAIN7 NLAG $=24$;

ESTIMATE $P=(1,15)(12) \mathrm{Q}=(2)$ ML PLOT;

TITLE1 'REGION 7: FIRST ARIMA';

IDENTIFY VAR=REGION7 CROSSCORR=(RAIN7 DUM1 DUM2 DUM3

DUM4 DUM5 DUM6 DUM7 DUM8 DUM9 DUM10 DUM11 DUM12) NLAG=22;

ESTIMATE $\mathrm{P}=(1,7,17) \mathrm{Q}=(11)$ ML PLOT NOINT

INPUT $=((1,2,3,4,5,7)$ RAIN7 DUM1 DUM2

DUM3 DUM4 DUM5 DUM6 DUM7 DUM8 DUM9 DUM10 DUM11 DUM12)

OUTEST=ESTS;

\%PARAMETR

ADJUST DATA FOR SEASONALITY AND PRECIPITATION CORRELATION **;

DATA NAT7; SET ONE3;

MEANS7=I2_1*DUM1+ I3_1*DUM2 + I4_1*DUM3 + I5_1* DUM4 + I6_1*DUM5+ I7_1*DUM6 +I8_1*DUM7+I9_1* DUM8+

I10_1*DUM9+I11_1*DUM10+I12_1*DUM11+I13_1*DUM12;

MEANR7=I1_1*RAIN7-I1_2*LAG(RAIN7)-11_3*LAG2(RAIN7)-

I1_4*LAG3(RAIN7)-I1_5*LAG4(RAIN7)-I1_6*LAG5(RAIN7)-

I1_7*LAG7(RAIN7);

VARS7 $=($ S2_1**2)*DUM1 + (S3_1**2)*DUM2 + (S4_1*2)*DUM3 +

$\left(\mathrm{S} 5 \text { 1 }{ }^{* * 2}\right)^{*} \mathrm{DUM} 4+\left(\mathrm{S} 6 \_1^{* * 2}\right)^{*} \mathrm{DUM} 5+\left(\mathrm{S} 71^{* * 2}\right)^{*} \mathrm{DUM} 6+$

$\left(\text { S8_1**2)*DUM7 + (S9_1**2)*DUM8 + (S10_1 }{ }^{* * 2}\right)^{*}$ DUM9 +

$\left(\mathrm{S} 11 \_1^{* * 2}\right)^{*}$ DUM10 + (S12_1 $\left.{ }^{* *} 2\right)^{*}$ DUM11 + (S13_1**2)*DUM12; 


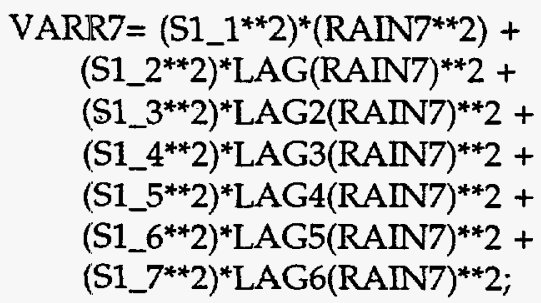

\%DROP1

NEWNAT7=REGION7-MEANS7-MEANR7;

*??? REGION 6 ;

PROC ARIMA DATA=ONES;

IDENTIFY VAR=RAIN6 NLAG=24;

ESTIMATE $P=(1,19,22) \mathrm{Q}=(4)(12)$ ML PLOT;

TITLE1 'REGION 6: FIRST ARIMA';

IDENTIFY VAR=REGION6 CROSSCORR=(RAIN6 DUM1 DUM2 DUM3

DUM4 DUM5 DUM6 DUM7 DUM8 DUM9 DUM10 DUM11 DUM12) NLAG=22;

ESTIMATE $P=(1,2)$ ML PLOT NOINT

INPUT $=((1,2,3,4,5,7)$ RAIN6 DUM1 DUM2

DUM3 DUM4 DUM5 DUM6 DUM7 DUM8 DUM9 DUM10 DUM11 DUM12)

OUTEST=ESTS;

\section{\%PARAMETR}

**** ADJUST DATA FOR SEASONALITY AND PRECIPITATION CORRELATION **;

DATA NAT6; SET ONE3;

MEANS6=I2_1*DUM1+ I3_1*DUM2 + I4_1*DUM3 + I5_1* DUM4 +

I6_1*DUM5+ I7_1*DUM6 +18_1*DUM7+I9_1* DUM8+

I10_1*DUM9+I11_1*DUM10+I12_1*DUM11+I13_1*DUM12;

MEANR6=I1_1*RAIN6-I1_2*LAG(RAIN6)-I1_3*LAG2(RAIN6)-

I1_4*LAG3(RAIN6)-I1_5*LAG4(RAIN6)-I1_6*LAG5(RAIN6)-

I1_7*LAG7(RAIN6);

VARS6 $=($ S2_1**2)*DUM1 + (S3_1*2)*DUM2 + (S4_1*2)*DUM3 +

$($ S5_1 1*2)*DUM4 + (S6_1**2)*DUM5 + (S7_1**2)*DUM6 +

$(\mathrm{S} 8$ 1 $1 * * 2) *$ DUM7 + $(\mathrm{S} 9$-1**2)*DUM8 + (S10_1**2)*DUM9 +

$\left(\mathrm{S} 11 \_1^{* *} 2\right)^{*} \mathrm{DUM} 10+\left(\mathrm{S} 12 \_1^{* *}\right)^{*} \mathrm{DUM} 11+\left(\mathrm{S} 13 \_1 * * 2\right)^{*} \mathrm{DUM} 12$

VARR6 $=\left(\mathrm{S}_{1} 1^{* *} 2\right)^{*}\left(\mathrm{RAIN}^{* *} 2\right)+$

$($ S1_2**2)*LAG(RAIN6)**2 +

$\left(\right.$ S1_3**2)*LAG2(RAIN6) ${ }^{* * 2}+$

$\left(\right.$ S1_4**2)*LAG3(RAIN6) ${ }^{* *} 2+$

$\left(\mathrm{S} 15^{* * 2}\right)^{*}$ LAG4(RAIN6) $)^{* * 2}+$

$($ S1_6**2)*LAG5(RAIN6)**2 +

$\left(\mathrm{S} 1 \_7^{* *} 2\right)^{*}$ LAG7(RAIN6)**2; 
$\% D R O P 1$

NEWNAT6=REGION6-MEANS6-MEANR6;

*??? REGION 5 ;

PROC ARIMA DATA=ONES;

IDENTIFY VAR=RAIN5 NLAG=24;

ESTIMATE $P=(1,7,9) \mathrm{Q}=(12)$ ML PLOT;

TITLE1 'REGION 5: FIRST ARIMA';

IDENTIFY VAR=REGION5 CROSSCORR=(RAIN5 DUM1 DUM2 DUM3

DUM4 DUM5 DUM6 DUM7 DUM8 DUM9 DUM10 DUM11 DUM12) NLAG=22;

ESTIMATE $\mathrm{P}=(1,3,7)$ ML PLOT NOINT

INPUT $=((1,2,3,4,5,6,7)$ RAIN5 DUM1 DUM2

DUM3 DUM4 DUM5 DUM6 DUM7 DUM8 DUM9 DUM10 DUM11 DUM12)

OUTEST=ESTS;

\section{\%PARAMETR}

**** ADJUST DATA FOR SEASONALITY AND PRECIPITATION CORRELATION **;

DATA NAT5; SET ONE3;

MEANS5=I2_1*DUM1+ I3_1*DUM2 + I4_1*DUM3 + I5_1*DUM4 + I6_1*DUM5+ I7_1*DUM6 +18_1*DUM7+19_1* DUM8+

I10_1*DUM9+I11_1*DUM10+I12_1*DUM11+I13_1*DUM12;

MEANR5=I1_1*RAIN5-I1_2*LAG(RAIN5)-I1_3*LAG2(RAIN5)-

I1_4*LAG3(RAIN5)-I1_5*LAG4(RAIN5)-I1_6*LAG5(RAIN5)-

I1_7*LAG6(RAIN5)-I1_8*LAG7(RAIN5);

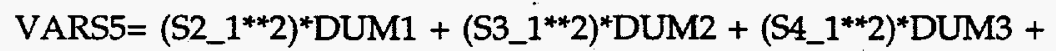

$(\text { S5_1 1*2) })^{*}$ DUM4 + (S6_1**2)*DUM5 + (S7_1*22)*DUM6 +

$\left(\mathrm{S} 8 \_11^{* * 2}\right)^{*} \mathrm{DUM} 7+\left(\mathrm{S} 9 \_1 * * 2\right)^{*} \mathrm{DUM} 8+\left(\mathrm{S} 1 \overline{0}_{-} 1^{* * 2}\right)^{*} \mathrm{DUM} 9+$

$\left(\mathrm{S} 11 \_1 * 2\right) *$ DUM10 + $($ S12_1**2)*DUM11 + (S13_1**2)*DUM12;

VARR5 $=(\text { S1_ } 1 * * 2)^{*}\left(\right.$ RAIN5 $\left.{ }^{* *} 2\right)+$

$($ S1_2**2)*LAG(RAIN5)**2+

$($ S1_3**2)*LAG2(RAIN5)**2 +

$\left(\mathrm{S} 14^{* *} 2\right)^{*} \mathrm{LAG}(\mathrm{RAIN} 5)^{* * 2}+$

$($ S1_5**2)*LAG4(RAIN5)**2 +

$($ S1_6**2)*LAG5(RAIN5)**2 +

$($ S1_7**2)*LAG6(RAIN5)**2+

$($ S1_8**2)*LAG7(RAIN5)**2;

\%DROP1

NEWNAT5=REGION5-MEANS5-MEANR5; 
*??? REGION 4 ;

PROC ARIMA DATA=ONES;

IDENTIFY VAR=RAIN4 NLAG=24;

ESTIMATE $P=(1,3,7,10,19) \mathrm{Q}=(1)$ ML PLOT;

TITLE1 'REGION 4: FIRST ARIMA';

IDENTIFY VAR=REGION4 CROSSCORR=(RAIN4 DUM1 DUM2 DUM3

DUM4 DUM5 DUM6 DUM7 DUM8 DUM9 DUM10 DUM11 DUM12) NLAG=22;

ESTIMATE $\mathrm{P}=(1,8) \mathrm{Q}=(11)(12)$ ML PLOT NOINT

INPUT $=((9,10,13,14)$ RAIN4 DUM1 DUM2

DUM3 DUM4 DUM5 DUM6 DUM7 DUM8 DUM9 DUM10 DUM11 DUM12)

OUTEST=ESTS;

\%PARAMETR

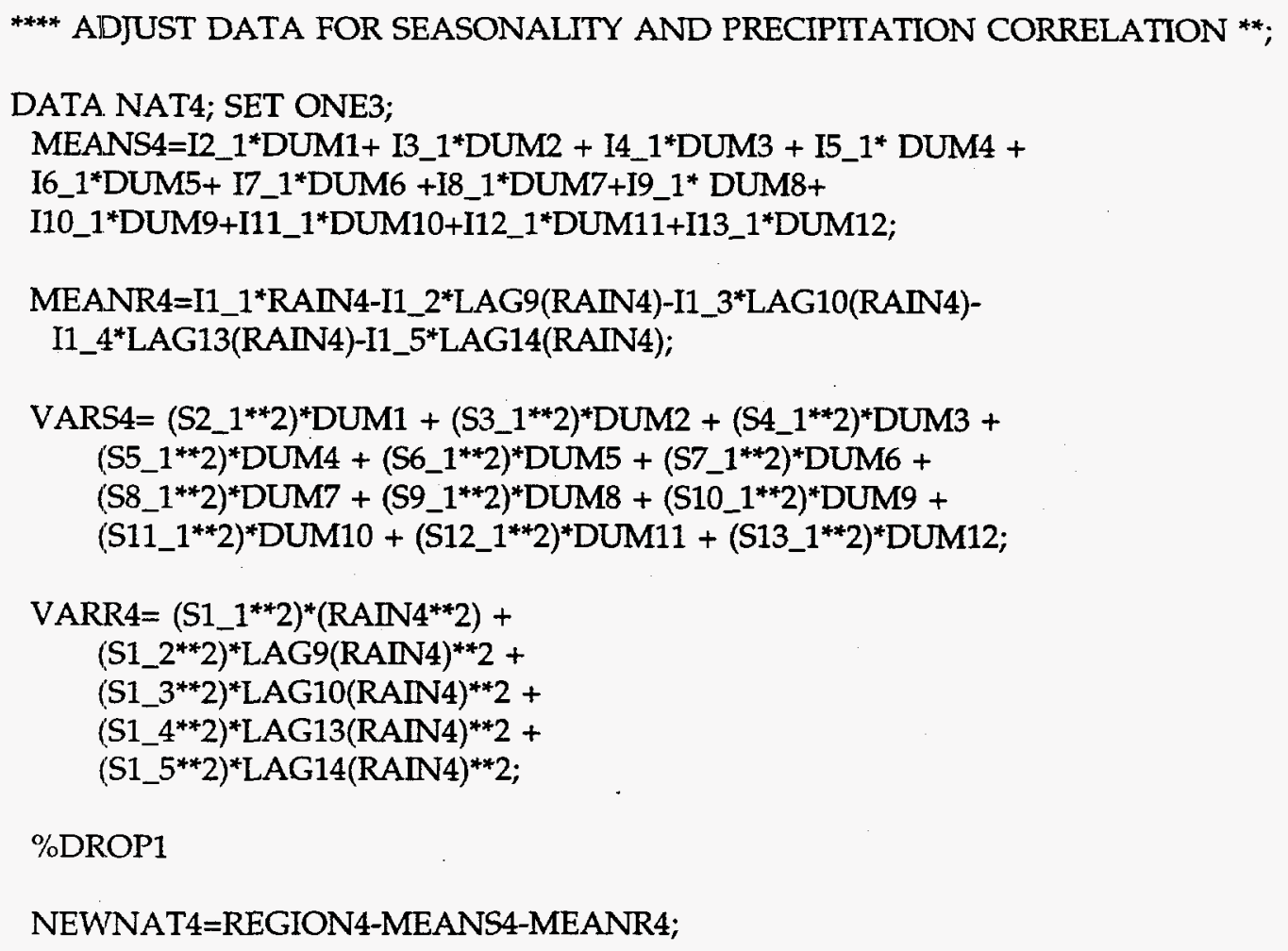


IDENTIFY VAR=REGION3 CROSSCORR=(RAIN3 DUM1 DUM2 DUM3

DUM4 DUM5 DUM6 DUM7 DUM8 DUM9 DUM10 DUM11 DUM12) NLAG=22;

ESTIMATE $P=(1,5)$ ML PLOT NOINT

INPUT $=((1,2,3,4,6)$ RAIN3 DUM1 DUM2

DUM3 DUM4 DUM5 DUM6 DUM7 DUM8 DUM9 DUM10 DUM11 DUM12)

OUTEST=ESTS;

\section{\%PARAMETR}

**** ADJUST DATA FOR SEASONALITY AND PRECIPITATION CORRELATION **;

DATA NAT3; SET ONE3;

MEANS3=I2_1*DUM1+ I3_1*DUM2 + I4_1*DUM3 + I5_1* DUM4 + 16_1*DUM5+17_1*DUM6 +18_1*DUM7+19_1* DUM8+

I10_1*DUM9+I11_1*DUM10+I12_1*DUM11+I13_1*DUM12;

MEANR3=I1_1*RAIN3-I1_2*LAG(RAIN3)-I1_3*LAG2(RAIN3)-

I1_4*LAG3(RAIN3)-I1_5*LAG4(RAIN3)-I1_6*LAG6(RAIN3);

VARS3 $=(\text { S2_1**2)*DUM1 + (S3_1*2)*DUM2 + (S4_1*2 })^{*}$ DUM3 +

$\left(\mathrm{S} 51^{* * 2}\right)^{*}$ DUM4 + (S6_1**2)*DUM5 + (S7_1**2)*DUM6 +

$\left(\mathrm{S} 8 \_1 * 2\right){ }^{*} \mathrm{DUM} 7+\left(\mathrm{S} 91^{* * 2}\right)^{*} \mathrm{DUM} 8+\left(\mathrm{S} 10 \_11^{* *} 2\right)^{*} \mathrm{DUM} 9+$

$\left(\mathrm{S} 11 \_1^{* * 2}\right) *$ DUM10 + $($ S12_1**2)*DUM11 + (S13_1**2)*DUM12;

VARR3 $=\left(\mathrm{S} 1 \_1 * * 2\right) *\left(\right.$ RAIN3 $\left.{ }^{* * 2}\right)+$

$($ S1_2**2)*LAG(RAIN3)**2 +

$($ S1_3**2)*LAG2(RAIN3)**2 +

$($ S1_4**2)*LAG3(RAIN3)**2 +

$\left(\mathrm{S} 15^{* *} 2\right)^{*}$ LAG4(RAIN3)**2 +

$\left(\mathrm{S} 1 \_6 * 2\right)^{*}$ LAG6(RAIN3)**2;

\%DROP1

NEWNAT3=REGION3-MEANS3-MEANR3;

*??? REGION 2 ;

PROC ARIMA DATA=ONES;

IDENTIFY VAR=RAIN2 NLAG=24;

ESTIMATE $P=(1,17)$ ML PLOT;

TITLE1 'REGION 2: FIRST ARIMA';

IDENTIFY VAR=REGION2 CROSSCORR=(RAIN2 DUM1 DUM2 DUM3

DUM4 DUM5 DUM6 DUM7 DUM8 DUM9 DUM10 DUM11 DUM12) NLAG=22;

ESTIMATE $P=(1,8) Q=(1)$ ML PLOT NOINT

INPUT $=((1,2,3,4,5,8,9)$ RAIN2 DUM1 DUM2

DUM3 DUM4 DUM5 DUM6 DUM7 DUM8 DUM9 DUM10 DUM11 DUM12)

OUTEST=ESTS;

\%PARAMETR 


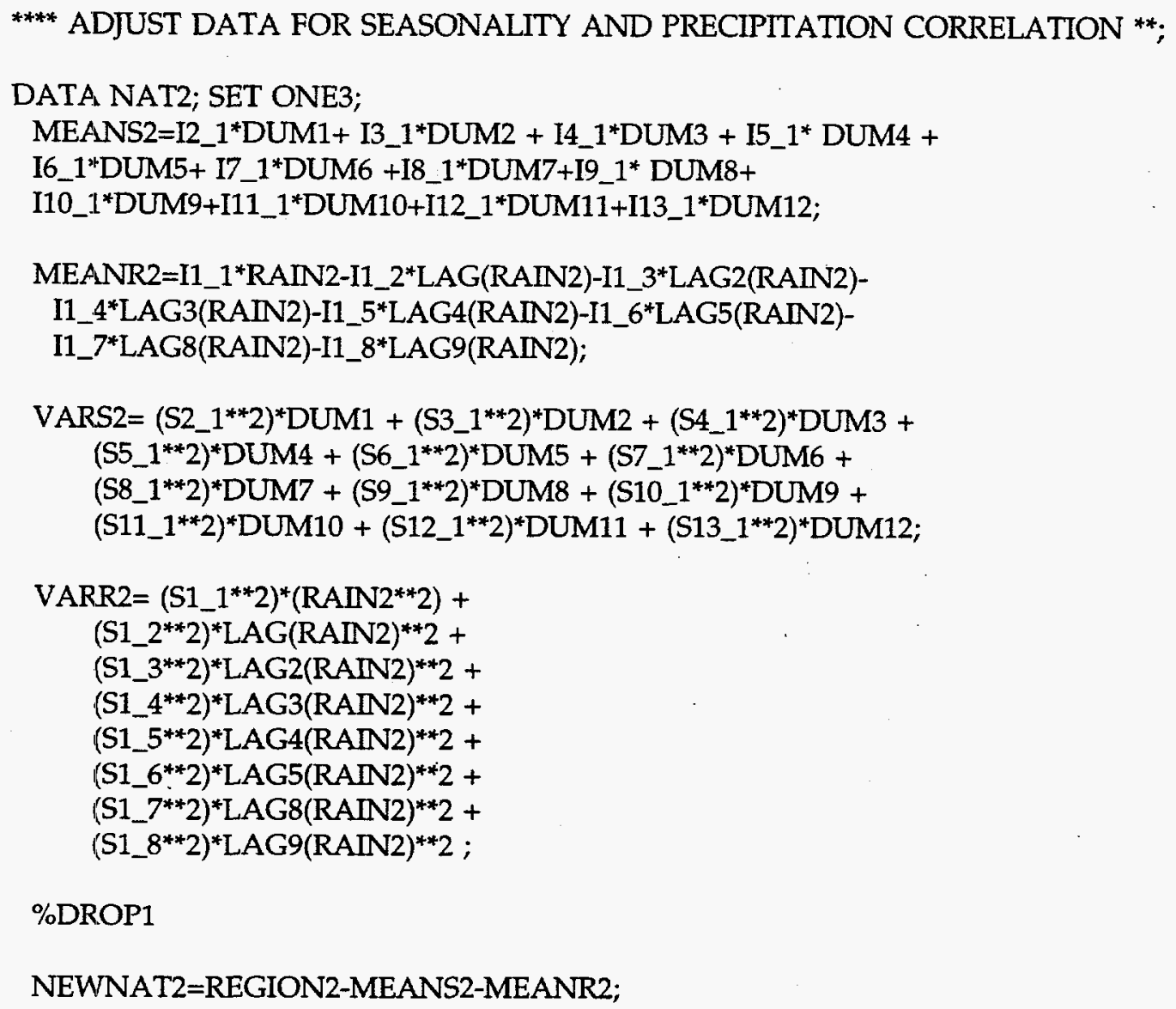

NEWNAT2=REGION2-MEANS2-MEANR2;

*??? REGION 1 ;

PROC ARMMA DATA=ONES;

IDENTIFY VAR=RAIN1 NLAG=24;

ESTTMATE P=(3) ML PLOT;

TTTLE1 'REGION 1: FIRST ARIMA';

IDENTIFY VAR=REGION1 CROSSCORR=(RAIN1 DUM1 DUM2 DUM3

DUM4 DUM5 DUM6 DUM7 DUM8 DUM9 DUM10 DUM11 DUM12) NLAG=22;

ESTIMATE $P=(1,9)$ ML PLOT NOINT

INPUT $=((1,2,3,4,5,7)$ RAIN1 DUM1 DUM2

DUM3 DUM4 DUM5 DUM6 DUM7 DUM8 DUM9 DUM10 DUM11 DUM12)

OUTEST=ESTS;

\%PARAMETR

*** ADJUST DATA FOR SEASONALITY AND PRECIPITATION CORRELATION **;

DATA NAT1; SET ONE3;

MEANS1=I2_1*DUM1+ I3_1*DUM2 + I4_1*DUM3 + I5_1* DUM4 + I6_1*DUM5+ I7_1*DUM6 +I8_1*DUM7+19_1* DUM8+

I10_1*DUM9+I11_1*DUM10+I12_1*DUM11+I13_1*DUM12; 


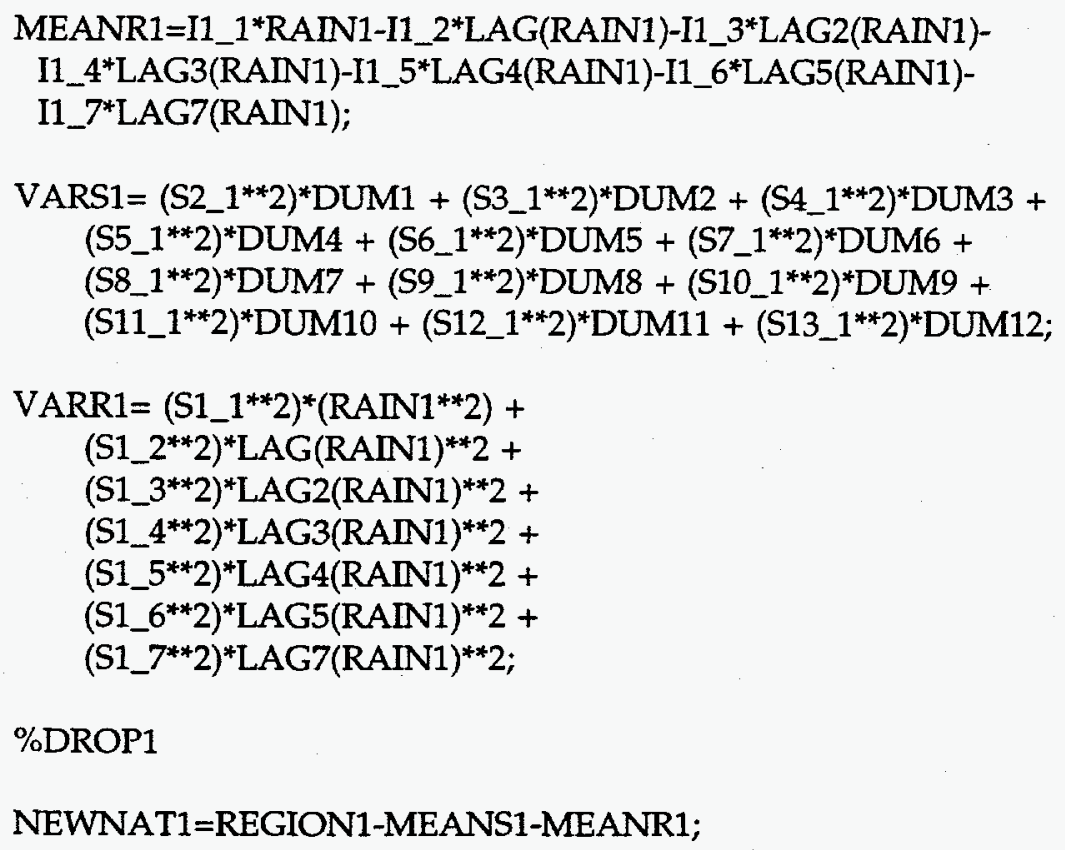

$\%$ DROP1

NEWNAT1=REGION1-MEANS1-MEANR1;

**** MERGE ALL DATA SETS WITH ALTERED DATA ****;

DATA NAT;

MERGE NAT1 (IN=A) NAT2 (IN=B) NAT3 (IN=C) NAT4 (IN=D) NAT5 (IN=E)

NAT6 (IN=F) NAT7 (IN=G) NAT8 (IN=H) NAT9 (IN=I);

BY YR MONTH;

IF (A OR B OR C OR D OR E OR F OR G OR H OR I) THEN OUTPUT;

**** BEGIN ALL REGIONS TOGETHER ****;

DATA NATS; SET NAT;

IF _N_ LE NUMAA;

**** RUN ARIMA WITH ADJUSTED DATA ****;

*??? REGION 9 ****;

PROC ARIMA DATA=NATS;

IDENTIFY VAR=NEWNAT9 NLAG $=24$;

ESTIMATE $P=(1,9) Q=(1,4,8,15,17)(12,13)$ ML PLOT NOINT;

TITLE 'REGION 9: SECOND ARIMA';

FORECAST LEAD $=36$ OUT $=$ OUTNAT;

DATA OUTNAT9; SET OUTNAT;

\%YRCAL

FORE9=FORECAST;

STDEV9=STD; 
*??? REGION 8 ****;

PROC ARIMA DATA=NATS;

IDENTIFY VAR=NEWNAT8 NLAG $=24$;

ESTIMATE $P=(1) \mathrm{Q}=(2)$ ML PLOT NOINT;

TITLE 'REGION 8: SECOND ARIMA';

FORECAST LEAD=36 OUT=OUTNAT;

DATA OUTNAT8; SET OUTNAT;

$\%$ YRCAL

FORE8=FORECAST;

STDEV8=STD;

*??? REGION 7 ****;

PROC ARIMA DATA=NATS;

IDENTIFY VAR $=$ NEWNAT7 NLAG $=24$;

ESTIMATE $P=(1,7,17) \mathrm{Q}=(11)$ ML PLOT NOINT;

TITLE 'REGION 7: SECOND ARIMA';

FORECAST $L E A D=36$ OUT=OUTNAT;

DATA OUTNAT7; SET OUTNAT;

\%YRCAL

FORE7=FORECAST;

STDEV7=STD;

*??? REGION 6 ****;

PROC ARIMA DATA=NATS;

IDENTIFY VAR=NEWNAT6 NLAG $=24$;

ESTIMATE $P=(1,2)$ ML PLOT NOINT;

TITLE 'REGION 6: SECOND ARIMA';

FORECAST LEAD=36 OUT=OUTNAT;

DATA OUTNAT6; SET OUTNAT;

$\%$ YRCAL

FORE6=FORECAST;

STDEV6=STD;

*??? REGION 5 ****;

PROC ARIMA DATA=NATS;

IDENTIFY VAR=NEWNAT5 NLAG $=24$;

ESTIMATE $\mathrm{P}=(1,3,7)$ ML PLOT NOINT;

TITLE 'REGION 5: SECOND ARIMA';

FORECAST LEAD=36 OUT=OUTNAT;

DATA OUTNAT5; SET OUTNAT;

$\%$ YRCAL

FORE5=FORECAST;

STDEV5=STD; 
*??? REGION 4 ****;

PROC ARIMA DATA=NATS;

IDENTIFY VAR=NEWNAT4 NLAG=24;

ESTIMATE $\mathrm{P}=(\mathbf{1}, \mathbf{8}) \mathrm{Q}=(\mathbf{1 1})(12)$ ML PLOT NOINT;

TITLE 'REGION 4: SECOND ARIMA';

FORECAST LEAD=36 OUT=OUTNAT;

DATA OUTNAT4; SET OUTNAT;

\%YRCAL

FORE4=FORECAST;

STDEV4=STD;

*??? REGION $3^{\text {****; }}$

PROC ARIMA DATA=NATS;

IDENTIFY VAR=NEWNAT3 NLAG $=24$;

ESTMMATE $P=(1,5)$ ML PLOT NOINT;

TITLE 'REGION 3: SECOND ARIMA';

FORECAST LEAD=36 OUT=OUTNAT;

DATA OUTNAT3; SET OUTNAT;

$\%$ YRCAL

FORE3=FORECAST;

STDEV3=STD;

*??? REGION 2 ****;

PROC ARIMA DATA=NATS;

IDENTIFY VAR $=$ NEWNAT2 NLAG $=24$;

ESTIMATE $P=(1,8) \mathrm{Q}=(1)$ ML PLOT NOINT;

TITLE 'REGION 2: SECOND ARIMA';

FORECAST LEAD=36 OUT=OUTNAT;

DATA OUTNAT2; SET OUTNAT;

$\%$ YRCAL

FORE2=FORECAST;

STDEV2=STD;

*??? REGION 1 ****;

PROC ARIMA DATA=NATS;

IDENTIFY VAR=NEWNAT1 NLAG $=24$;

ESTIMATE $P=(1,9)$ ML PLOT NOINT;

TITLE 'REGION 1: SECOND ARIMA';

FORECAST LEAD=36 OUT=OUTNAT;

DATA OUTNAT1; SET OUTNAT;

$\%$ YRCAL

FORE1=FORECAST;

STDEV1=STD; 


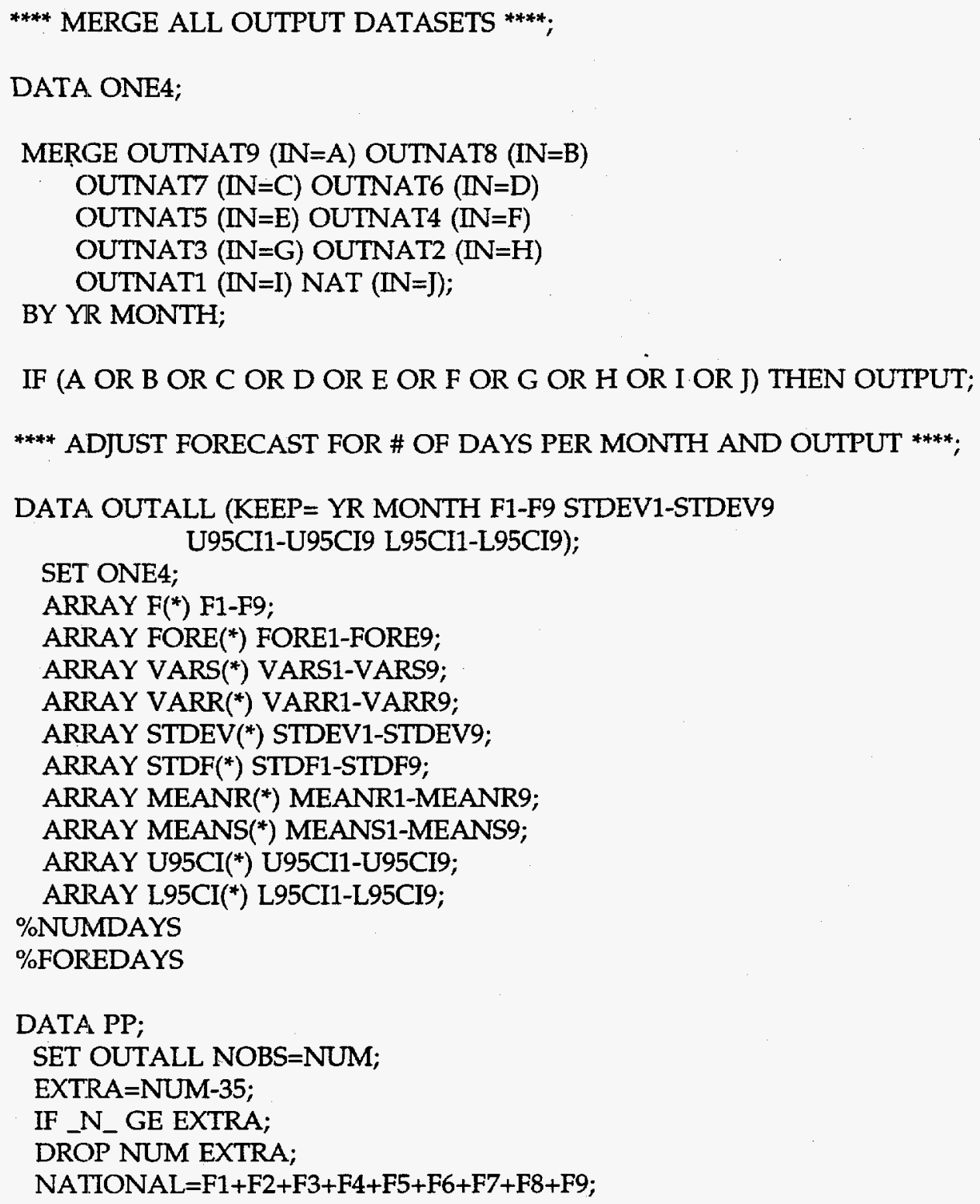

IF (A OR B OR C OR D OR E OR F OR G OR H OR I OR J) THEN OUTPUT;

PROC PRINT DATA=PP;

VAR YR MONTH F1-F9 NATIONAL;

TITLE 'FORECAST OF HYDROELECTRIC GENERATION BY REGION';

PROC PRINT DATA=PP;

VAR YR MONTH U95CI1-U95CI9;

TITLE 'UPPER $95 \%$ CONFIDENCE INTERVAL';

PROC PRINT DATA $=P P$;

VAR YR MONTH L95CI1-L95CI9;

TITLE 'LOWER $95 \%$ CONFIDENCE INTERVAL'; 


\section{Variable Definitions}

YR

MONTH month

REGION(*) array of regional hydroelectric generation data

NUMAA number of observations of national hydroelectric generation data

RAIN(*) array of regional precipitation data

NUMRR

DAYS $_{k}$

$\mathrm{DUM}_{t, k}$

MEANS $(*)$

$\operatorname{MEANR}(*)$

VARS $(*)$

$\operatorname{VARR}\left({ }^{\star}\right)$

NEWNAT $\left(^{*}\right)$

$F\left({ }^{*}\right)$

FORE $\left({ }^{*}\right)$

$\operatorname{STDF}\left({ }^{*}\right)$

STDEV $\left({ }^{\star}\right)$

$\mathrm{U} 95 \mathrm{Cl}(*)$

L95Cl( $\left.{ }^{*}\right)$

NATIONAL number of observations of national precipitation data

number of days in month $k$

monthly dummy variables where $\mathrm{DUM}_{t, k}=1$ if $t$ observed in month $k$ and $\mathrm{DUM}_{t, k}=0$ otherwise

array of average seasonal effect of the hydroelectric generation data for each region; calculated using coefficients of the dummy variables from the procedure ARIMA runs

array of average impact of past and present changes in precipitation for each region; calculated using coefficients of the lags of the correlated precipitation data from the procedure ARIMA runs

array of variance of the estimated seasonal mean of the hydroelectric generation data for each region

array of variance of the estimated mean of the changes in precipitation for each region; calculated using the approximate standard error of the estimated coefficients from the procedure ARIMA runs

array of regional hydroelectric generation data which has been adjusted for the effects of seasonality and assumed normal forecasted precipitation

array of readjusted regional forecasts for hydroelectric generation

array of regional forecasts of hydroelectric generation from the procedure ARIMA run on the adjusted hydroelectric generation data

array of estimations of the standard deviation of the readjusted regional hydroelectric generation forecast

array of standard deviations for the regional hydroelectric generation from the procedure ARIMA run on the adjusted regional hydroelectric generation data

array of estimated upper 95 percent confidence intervals for the readjusted regional hydroelectric generation forecasts

array of estimated lower 95 percent confidence intervals for the readjusted regional hydroelectric generation forecasts

national hydroelectric generation data 


\section{Appendix C. Data}

Table C1. Out of Sample and STEO Forecasts Using Actual Data through 1989 Compared with Actual Hydroelectric Generation, 1990-1991

\begin{tabular}{|c|c|c|c|c|}
\hline \multirow[b]{2}{*}{ Year } & \multirow[b]{2}{*}{ Month } & \multirow{2}{*}{$\begin{array}{c}\text { Net } \\
\text { Hydroelectric } \\
\text { Generation } \\
\end{array}$} & \multicolumn{2}{|c|}{ Forecasts } \\
\hline & & & STHGM & STEO \\
\hline \multirow[t]{12}{*}{1989} & January & 20.9 & NA & NA \\
\hline & February & 18.6 & NA & NA \\
\hline & March & 22.6 & NA & NA \\
\hline & April & 24.1 & NA & NA \\
\hline & May & 28.0 & NA & NA \\
\hline & June & 25.9 & NA & NA \\
\hline & July & 22.7 & NA & NA \\
\hline & August & 20.2 & NA & NA \\
\hline & September & 18.9 & NA & NA \\
\hline & October & 20.1 & NA & NA \\
\hline & November & 21.2 & NA & NA \\
\hline & December & 21.8 & NA & NA \\
\hline \multirow[t]{12}{*}{1990} & January & 23.4 & 23.4 & 22.2 \\
\hline & February & 24.2 & 22.1 & 20.7 \\
\hline & March & 28.0 & 25.1 & 22.7 \\
\hline & April & 25.4 & 24.4 & 24.5 \\
\hline & May & 27.0 & 26.9 & 27.3 \\
\hline & June & 27.7 & 25.9 & 25.8 \\
\hline & July & 23.7 & 23.3 & 23.9 \\
\hline & August & 21.0 & 20.4 & 21.9 \\
\hline & September & 17.0 & 18.2 & 19.6 \\
\hline & October & 18.6 & 18.9 & 19.9 \\
\hline & November & 20.0 & 20.7 & 22.0 \\
\hline & December & 24.0 & 23.8 & 25.6 \\
\hline \multirow[t]{12}{*}{1991} & January & 25.7 & 24.4 & 26.5 \\
\hline & February & 21.9 & 22.3 & 24.5 \\
\hline & March & 25.8 & 24.9 & 26.7 \\
\hline & April & 25.7 & 24.2 & 26.2 \\
\hline & May & 28.5 & 25.7 & 28.2 \\
\hline & June & 25.8 & 24.7 & 26.6 \\
\hline & July & 24.3 & 23.1 & 24.7 \\
\hline & August & 21.7 & 21.0 & 22.2 \\
\hline & September & 18.4 & 18.6 & 19.9 \\
\hline & October & 17.5 & 18.7 & 19.9 \\
\hline & November & 18.3 & 20.2 & 22.0 \\
\hline & December & 21.9 & 23.4 & 25.6 \\
\hline
\end{tabular}

Notes: -All forecasts are based on actual generation and precipitation data through the indicated year. -All forecasts assume normal precipitation during the forecast period.

Source: STEO Forecasts: Energy Information Administration, Office of Coal, Nuclear, Electric, and Alternate Fuels memo to Office of Energy Markets and End Use dated March 13,1990. STHGM Forecasts: Energy Information Administration, STHGM run using HYDRO.TIME.SERIES.FINAL.D060193. Actual: Energy Information Administration, Form ElA-759, "Monthly Power Plant Report." 
Table C2. Out of Sample and STEO Forecasts Using Actual Data through 1990 Compared with Actual Hydroelectric Generation, 1991-1992

\begin{tabular}{|c|c|c|c|c|}
\hline \multirow[t]{2}{*}{ Year } & \multirow[t]{2}{*}{ Month } & \multirow{2}{*}{$\begin{array}{c}\text { Net } \\
\text { Hydroelectric } \\
\text { Generation }\end{array}$} & \multicolumn{2}{|c|}{ Forecast } \\
\hline & & & STHGM & STEO \\
\hline \multirow[t]{12}{*}{1990} & January & 23.4 & NA & NA \\
\hline & February & 24.2 & NA & NA \\
\hline & March & 28.0 & NA & NA \\
\hline & April & 25.4 & NA & NA \\
\hline & May & - 27.0 & NA & NA \\
\hline & June & 27.7 & NA & NA \\
\hline & July & 23.7 & NA & NA \\
\hline & August & 21.0 & NA & NA \\
\hline & September & 17.0 & NA & NA \\
\hline & October & 18.6 & NA & NA \\
\hline & November & 20.0 & NA & NA \\
\hline & December & 24.0 & NA & NA \\
\hline \multirow[t]{2}{*}{1991} & January & 25.7 & 24.4 & 24.2 \\
\hline & February & 21.9 & 22.0 & 23.0 \\
\hline \multirow[t]{10}{*}{ • } & March & 25.8 & 25.1 & 26.3 \\
\hline & April & 25.7 & 24.5 & 25.6 \\
\hline & May & 28.5 & 25.2 & 27.8 \\
\hline & June & 25.8 & 24.3 & 25.9 \\
\hline & July & 24.3 & 23.3 & 24.7 \\
\hline & August & 21.7 & 21.1 & 22.6 \\
\hline & September & 18.4 & 18.7 & 20.3 \\
\hline & October & 17.5 & 18.3 & 20.3 \\
\hline & November & 18.3 & 19.8 & 22.4 \\
\hline & December & 21.9 & 23.1 & 26.0 \\
\hline \multirow[t]{12}{*}{1992} & January & 21.5 & 24.5 & 25.0 \\
\hline & February & 18.0 & 23.1 & 23.8 \\
\hline & March & 21.6 & 25.1 & 27.2 \\
\hline & April & 19.5 & 24.4 & 26.5 \\
\hline & May & 22.3 & 26.0 & 28.7 \\
\hline & June & 22.7 & 24.8 & 26.8 \\
\hline & July & 19.7 & 23.5 & 25.5 \\
\hline & August & 18.1 & 21.4 & 23.4 \\
\hline & September & 16.8 & 19.0 & 21.0 \\
\hline & October & 16.4 & 19.0 & 21.0 \\
\hline & November & 19.3 & 20.4 & 23.2 \\
\hline & December & 23.8 & 23.5 & 26.9 \\
\hline
\end{tabular}

Notes: -All forecasts are based on actual generation and precipitation data through the indicated year. -All forecasts assume normal precipitation during the forecast period.

Source: STEO Forecasts: Energy Information Administration, Office of Coal, Nuclear, Electric, and Alternate Fuels memo to Office of Energy Markets and End Use dated March 19, 1991. STHGM Forecasts: Energy Information Administration, STHGM run using HYDRO.TIME.SERIES.FINAL.D060193. Actual: Energy Information Administration, Form EIA-759, "Monthly Power Plant Report." 
Table C3. Out of Sample and STEO Forecasts Using Actual Data through 1991 Compared with Actual Hydroelectric Generation, 1992-1993

\begin{tabular}{|c|c|c|c|c|}
\hline \multirow[t]{2}{*}{ Year } & \multirow[t]{2}{*}{ Month } & \multirow{2}{*}{$\begin{array}{c}\text { Net } \\
\text { Hydroelectric } \\
\text { Generation }\end{array}$} & \multicolumn{2}{|c|}{ Forecasts } \\
\hline & & & STHGM & STEO \\
\hline \multirow[t]{12}{*}{1991} & January & 25.7 & NA & NA \\
\hline & February & 21.9 & NA & NA \\
\hline & March & 25.8 & NA & NA \\
\hline & April & 25.7 & NA & NA \\
\hline & May & 28.5 & NA & NA \\
\hline & June & 25.8 & NA & NA \\
\hline & July & 24.3 & NA & NA \\
\hline & August & 21.7 & NA & NA \\
\hline & September & 18.4 & NA & NA \\
\hline & October & 17.5 & NA & NA \\
\hline & November & 18.3 & NA & NA \\
\hline & December & 21.9 & NA & NA \\
\hline \multirow[t]{12}{*}{1992} & January & 21.5 & 23.6 & 24.8 \\
\hline & February & 18.0 & 22.3 & 21.7 \\
\hline & March & 21.6 & 23.8 & 25.4 \\
\hline & April & 19.5 & 23.3 & 24.8 \\
\hline & May & 22.3 & 25.1 & 27.3 \\
\hline & June & 22.7 & 24.3 & 25.1 \\
\hline & July & 19.7 & 22.7 & 23.8 \\
\hline & August & 18.1 & 20.9 & 21.8 \\
\hline & September & 16.8 & 18.6 & 19.3 \\
\hline & October & 16.4 & 18.4 & 20.4 \\
\hline & November & 19.3 & 19.8 & 22.6 \\
\hline & December & 23.8 & 22.8 & 26.2 \\
\hline \multirow[t]{12}{*}{1993} & January & 24.5 & 24.1 & 26.8 \\
\hline & February & 19.7 & 22.2 & 24.6 \\
\hline & March & 23.6 & 25.0 & 27.1 \\
\hline & April & 25.2 & 24.3 & 26.2 \\
\hline & May & 29.3 & 25.9 & 28.3 \\
\hline & June & 26.6 & 24.9 & 26.3 \\
\hline & July & 23.6 & 23.3 & 24.2 \\
\hline & August & 19.7 & 21.3 & 22.4 \\
\hline & September & 17.1 & 18.9 & 20.6 \\
\hline & October & 16.9 & 19.0 & 20.8 \\
\hline & November & 17.9 & 20.4 & 22.6 \\
\hline & December & 21.1 & 23.6 & 26.2 \\
\hline
\end{tabular}

Notes: -All forecasts are based on actual generation and precipitation data through the indicated year. -All forecasts assume normal precipitation during the forecast period.

SOurce: STEO Forecasts: Energy Information Administration, Office of Coal, Nuclear, Electric, and Alternate Fuels memo to Office of Energy Markets and End Use dated March 6, 1992. STHGM Forecasts: Energy Information Administration, STHGM run using HYDRO.TIME.SERIES.FINAL.D060193. Actual: Energy Information Administration, Form ElA-759, "Monthly Power Plant Report." 
Table C4. Out of Sample (Regional STHGM) and STEO Forecasts Using Actual Generation Data through 1992 with Actual Hydroelectric Generation, 1993-1994

\begin{tabular}{|c|c|c|c|c|}
\hline \multirow[t]{2}{*}{ Year } & \multirow[t]{2}{*}{ Month } & \multirow{2}{*}{$\begin{array}{c}\text { Net } \\
\text { Hydroelectric } \\
\text { Generation } \\
\end{array}$} & \multicolumn{2}{|c|}{ Forecasts } \\
\hline & & & STHGM & STEO \\
\hline \multirow[t]{12}{*}{1992} & January & 21.5 & NA & NA \\
\hline & February & 18.0 & NA & NA \\
\hline & March & 21.6 & NA & NA \\
\hline & April & 19.5 & NA & NA \\
\hline & May & 22.3 & NA & NA \\
\hline & June & 22.7 & NA & NA \\
\hline & July & 19.7 & NA & NA \\
\hline & August & 18.1 & NA & NA \\
\hline & September & 16.8 & NA & NA \\
\hline & October & 16.4 & NA & NA \\
\hline & November & 19.3 & NA & NA \\
\hline & December & 23.8 & NA & NA \\
\hline \multirow[t]{12}{*}{1993} & January & 24.5 & 24.1 & 22.9 \\
\hline & February & 19.7 & 21.3 & 20.6 \\
\hline & March & 23.6 & 23.4 & 23.6 \\
\hline & April & 25.2 & 23.4 & 24.5 \\
\hline & May & 29.3 & 25.4 & 27.3 \\
\hline & June & 26.6 & 24.9 & 24.8 \\
\hline & July & 23.6 & 23.4 & 24.1 \\
\hline & August & 19.7 & 20.6 & 21.6 \\
\hline & September & 17.1 & 18.6 & 19.9 \\
\hline & October & 16.9 & 18.7 & 20.6 \\
\hline & November & 17.9 & 20.4 & 21.7 \\
\hline & December & 21.1 & 23.7 & 24.5 \\
\hline \multirow[t]{12}{*}{1994} & January & 19.8 & 24.6 & 25.8 \\
\hline & February & 19.1 & 22.5 & 23.1 \\
\hline & March & 22.2 & 25.2 & 26.6 \\
\hline & April & 23.2 & 24.4 & 26.2 \\
\hline & May & 24.3 & 26.2 & 29.1 \\
\hline & June & 23.4 & 25.0 & 27.1 \\
\hline & July & 21.9 & 23.6 & 24.8 \\
\hline & August & 19.1 & 21.5 & 22.3 \\
\hline & September & 15.4 & 19.0 & 20.1 \\
\hline & October & 16.4 & 19.2 & 20.6 \\
\hline & November & 17.9 & 20.7 & 21.9 \\
\hline & December & 20.9 & 23.8 & 25.0 \\
\hline
\end{tabular}

Notes: All forecasts are based on actual generation data through 1992 and precipitation data through June of 1992 . A All forecasts assume normal precipitation after the last month of available actual data.

Source: STEO Forecasts: Energy Information Administration, Office of Coal, Nuclear, Electric, and Altemate Fuels memo to Office of Energy Markets and End Use dated March 8, 1993. STHGM Forecasts: Energy information Administration, STHGM run using HYDRO.MODEL. Actual: Energy Information Administration, Form EIA-759, "Monthly Power Plant Report." 
Table C5. Out of Sample (Regional STHGM) and STEO Forecasts Using Actual Generation Data through 1993 Compared with Actual Hydroelectric Generation, 1994-1995

\begin{tabular}{|c|c|c|c|c|}
\hline \multirow[t]{2}{*}{ Year } & \multirow[t]{2}{*}{ Month } & \multirow{2}{*}{$\begin{array}{c}\text { Net } \\
\text { Hydroelectric } \\
\text { Generation } \\
\end{array}$} & \multicolumn{2}{|c|}{ Forecasts } \\
\hline & & & STHGM & STEO \\
\hline \multirow[t]{12}{*}{1993} & January & 24.5 & NA & NA \\
\hline & February & 19.7 & NA & NA \\
\hline & March & 23.6 & NA & NA \\
\hline & April & 25.2 & NA & NA \\
\hline & May & 29.3 & NA & NA \\
\hline & June & 26.6 & NA & NA \\
\hline & July & 23.6 & NA & NA \\
\hline & August & 19.7 & NA & NA \\
\hline & September & 17.1 & NA & NA \\
\hline & October & 16.9 & NA & NA \\
\hline & November & 17.9 & NA & NA \\
\hline & December & 21.1 & NA & NA \\
\hline \multirow[t]{12}{*}{1994} & January & 19.8 & 22.0 & 22.9 \\
\hline & February & 19.1 & 19.6 & 20.8 \\
\hline & March & 22.2 & 22.4 & 23.0 \\
\hline & April & 23.2 & 22.4 & 22.9 \\
\hline & May & 24.3 & 25.3 & 25.4 \\
\hline & June & 23.4 & 25.0 & 25.0 \\
\hline & July & 21.9 & 23.1 & 22.8 \\
\hline & August & 19.1 & 20.6 & 20.3 \\
\hline & September & 15.4 & 18.5 & 17.8 \\
\hline & October & 16.4 & 18.5 & 18.1 \\
\hline & November & 17.9 & 20.5 & 19.5 \\
\hline & December & 20.9 & 23.4 & 22.6 \\
\hline \multirow[t]{12}{*}{1995} & January & 23.3 & 24.2 & 23.8 \\
\hline & February & 24.0 & 22.1 & 22.0 \\
\hline & March & 27.5 & 25.1 & 24.7 \\
\hline & April & 23.5 & 24.5 & 24.1 \\
\hline & May & 26.6 & 26.5 & 25.8 \\
\hline & June & 28.4 & 25.2 & 24.8 \\
\hline & July & 25.9 & 23.6 & 23.2 \\
\hline & August & 23.0 & 21.3 & 21.2 \\
\hline & September & 18.8 & 18.9 & 18.8 \\
\hline & October & 21.4 & 19.0 & 18.9 \\
\hline & November & 24.0 & 20.7 & 20.4 \\
\hline & December & 27.3 & 23.9 & 23.6 \\
\hline
\end{tabular}

Notes: -All forecasts are based on actual generation data through 1993 and precipitation data through June of 1993. -All forecasts assume normal precipitation after the last month of available actual data.

Source: STEO Forecasts: Energy Information Administration, Office of Coal, Nuclear, Electric, and Altemate Fuels memo to Otfice of Energy Markets and End Use dated March 7, 1994. STHGM Forecasts: Energy Information Administration, STHGM run using HYDRO.MODEL. Actual: Energy Information Administration, Form ElA-759, "Monthly Power Plant Report." 
Table C6. Out of Sample (Regional STHGM) and STEO Forecasts for Region 9 Using Actual Generation Data through 1993 Compared with Actual Hydroelectric Generation, 1994-1995

\begin{tabular}{|c|c|c|c|c|}
\hline \multirow[t]{2}{*}{ Year } & \multirow[t]{2}{*}{ Month } & \multirow{2}{*}{$\begin{array}{c}\text { Net } \\
\text { Hydroelectric } \\
\text { Generation }\end{array}$} & \multicolumn{2}{|c|}{ Forecasts } \\
\hline & & & STHGM & STEO \\
\hline \multirow[t]{12}{*}{1993} & January & 11.0 & NA & NA \\
\hline & February & 9.8 & NA & NA \\
\hline & March & 11.6 & NA & NA \\
\hline & April & 12.5 & NA & NA \\
\hline & May & 17.6 & NA & NA \\
\hline & June & 16.3 & NA & NA \\
\hline & July & 14.3 & NA & NA \\
\hline & August & 11.2 & NA & NA \\
\hline & September & 9.3 & NA & NA \\
\hline & October & 9.1 & NA & NA \\
\hline & November & 9.5 & NA & NA \\
\hline & December & 9.9 & NA & NA \\
\hline \multirow[t]{12}{*}{1994} & January & 9.6 & 10.8 & 12.4 \\
\hline & February & 9.1 & 9.6 & 11.3 \\
\hline & March & 10.3 & 10.9 & 12.5 \\
\hline & April & 10.5 & 11.3 & 12.4 \\
\hline & May & 12.9 & 14.1 & 13.8 \\
\hline & June & 13.5 & 14.5 & 13.6 \\
\hline & July & 11.7 & 13.1 & 12.4 \\
\hline & August & 8.8 & 11.1 & 11.0 \\
\hline & September & 7.0 & 9.8 & 9.7 \\
\hline & October & 7.9 & 9.7 & 9.8 \\
\hline & November & 8.6 & 10.9 & 10.6 \\
\hline & December & 10.4 & 12.4 & 12.2 \\
\hline 1995 & January & 12.6 & 12.9 & 12.9 \\
\hline & February & 14.1 & 12.0 & 11.9 \\
\hline & March & 15.6 & 13.5 & 13.4 \\
\hline & April & 15.0 & 13.2 & 13.1 \\
\hline & May & 17.0 & 15.1 & 14.0 \\
\hline & June & 18.2 & 14.5 & 13.5 \\
\hline & July & 15.6 & 13.4 & 12.6 \\
\hline & August & 12.5 & 11.7 & 11.5 \\
\hline & September & 10.3 & 10.0 & 10.2 \\
\hline & October & 11.5 & 10.1 & 10.3 \\
\hline & November & 12.5 & 11.0 & 11.1 \\
\hline & December & 16.5 & 12.7 & 12.8 \\
\hline
\end{tabular}

Notes: -All forecasts are based on actual generation data through 1993 and precipitation data through June of 1993 . All forecasts assume normal precipitation after the last month of available actual data.

Source: STEO Forecasts: Energy Information Administration, Office of Coal, Nuclear, Electric, and Alternate Fuels memo to Office of Energy Markets and End Use dated March 7, 1994. STHGM Forecasts: Energy Information Administration, STHGM run using HYDRO.MODEL. Actual: Energy Information Administration, Form EIA-759, "Monthly Power Plant Report." 
Table C7. Out of Sample (Regional STHGM) and STEO

Forecasts for Region 5 Using Actual Generation

Data through 1993 Compared with Actual

Hydroelectric Generation, 1994-1995

\begin{tabular}{|c|c|c|c|c|}
\hline \multirow[t]{2}{*}{ Year } & \multirow[t]{2}{*}{ Month } & \multirow{2}{*}{$\begin{array}{c}\text { Net } \\
\text { Hydroelectric } \\
\text { Generation }\end{array}$} & \multicolumn{2}{|c|}{ Forecasts } \\
\hline & & & STHGM & STEO \\
\hline \multirow[t]{12}{*}{1993} & January & 2.7 & NA & NA \\
\hline & February & 1.9 & NA & NA \\
\hline & March & 2.4 & NÁ & NA \\
\hline & April & 2.3 & NA & NA \\
\hline & May & 1.4 & NA & NA \\
\hline & June & 0.8 & NA & NA \\
\hline & July & 0.6 & NA & NA \\
\hline & August & 0.6 & NA & NA \\
\hline & September & 0.5 & NA & NA \\
\hline & October & 0.5 & NA & NA \\
\hline & November & 0.6 & NA & NA \\
\hline & December & 1.2 & NA & NA \\
\hline \multirow[t]{12}{*}{1994} & January & 1.2 & 1.4 & 1.3 \\
\hline & February & 1.5 & 1.3 & 1.2 \\
\hline & March & 1.9 & 1.7 & 1.3 \\
\hline & April & 1.9 & 1.5 & 1.3 \\
\hline & May & 0.9 & 1.3 & 1.4 \\
\hline & June & .9 & 1.0 & 1.4 \\
\hline & July & 1.1 & 0.9 & 1.3 \\
\hline & August & 1.8 & 0.9 & 1.1 \\
\hline & September & 1.1 & 0.8 & 1.0 \\
\hline & October & 1.1 & 0.9 & 1.0 \\
\hline & November & 1.1 & 1.1 & 1.1 \\
\hline & December & 1.4 & 1.4 & 1.3 \\
\hline \multirow[t]{12}{*}{1995} & January & 1.6 & 1.5 & 1.3 \\
\hline & February & 1.6 & 1.5 & 1.2 \\
\hline & March & 1.8 & 1.8 & 1.4 \\
\hline & April & 0.7 & 1.6 & 1.3 \\
\hline & May & 0.7 & 1.4 & 1.4 \\
\hline & June & 0.9 & 1.1 & 1.4 \\
\hline & July & 0.9 & 1.0 & 1.3 \\
\hline & August & 0.8 & 1.0 & 1.2 \\
\hline & September & 0.7 & 0.9 & 1.0 \\
\hline & October & 1.2 & 1.0 & 1.0 \\
\hline & November & 1.6 & 1.1 & 1.1 \\
\hline & December & 1.1 & 1.4 & 1.3 \\
\hline
\end{tabular}

Notes: -All forecasts are based on actual generation data through 1993 and precipitation data through June of 1993. -All forecasts assume normal precipitation after the last month of available actual data.

Source: STEO Forecasts: Energy Information Administration, Office of Coal, Nuclear, Electric, and Altemate Fuels memo to Otfice of Energy Markets and End Use dated March 7, 1994. STHGM Forecasts: Energy Information Administration, STHGM run using HYDRO.MODEL. Actual: Energy Information Administration, Form ElA-759, "Monthly Power Plant Report." 


\section{Appendix D. Census Divisions}

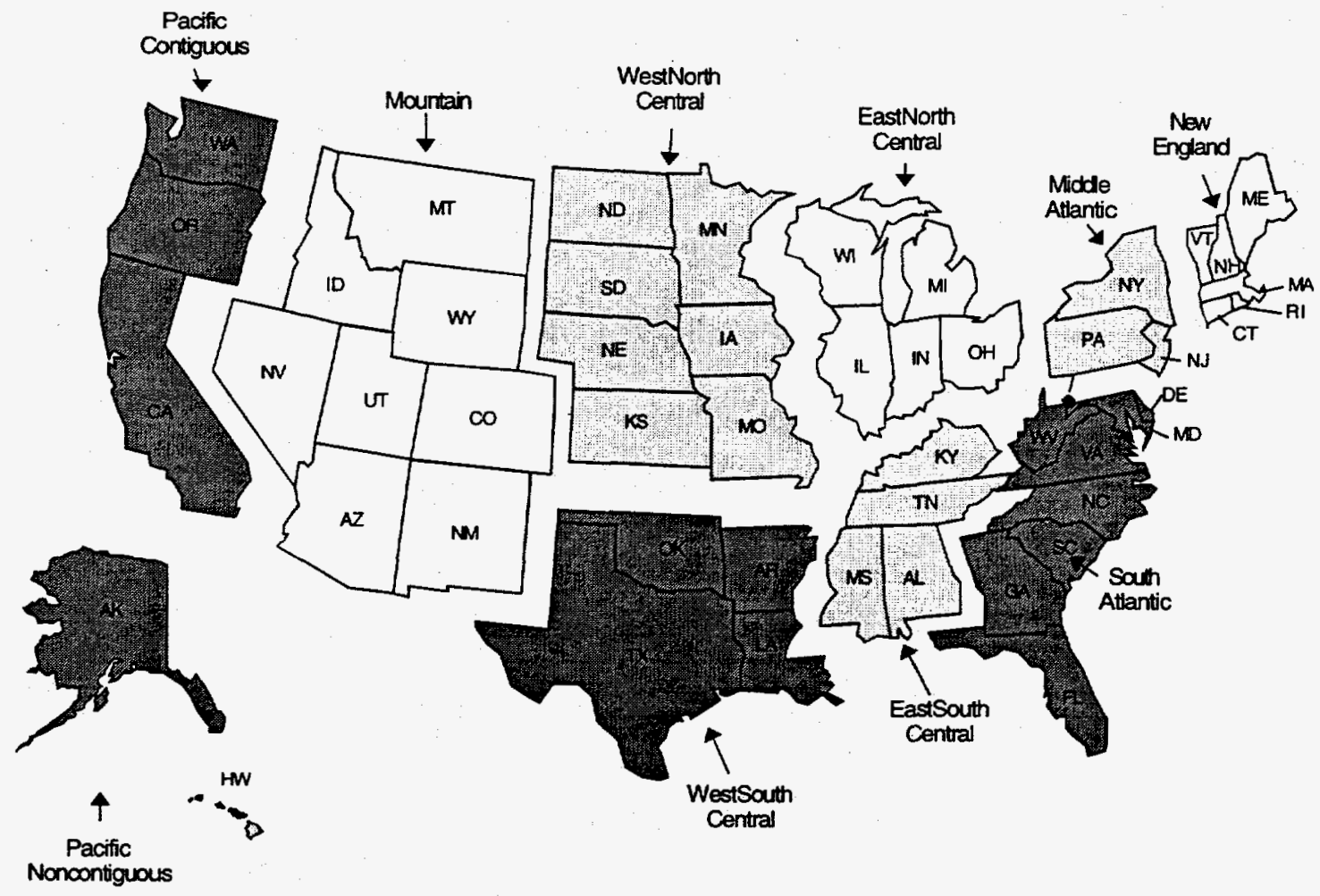

Source: United States Bureau of the Census. 


\section{Appendix E. ARIMA Output Containing Estimated Dummy Variable and Precipitation Lag Parameters for Each Region}

Table E1. REGION 1: FIRST ARIMA

ARIMA Procedure

Maximum Likelihood Estimation

\begin{tabular}{|c|c|c|c|c|c|c|}
\hline \multicolumn{7}{|c|}{ Approximate } \\
\hline Parameter & Estimate & Std Error & T Ratio & Lag & Variable & Shift \\
\hline AR1,1 & 0.32716 & 0.05697 & 5.74 & 1 & REGION1 & 0 \\
\hline AR1,2 & 0.09857 & 0.06022 & 1.64 & 9 & REGION1 & 0 \\
\hline NUM1 & 30.97437 & 2.60164 & 11.91 & 0 & RAIN1 & 0 \\
\hline NUM1,1 & -29.02922 & 2.67429 & -10.85 & 1 & RAIN1 & 0 \\
\hline NUM1,2 & -21.81069 & 2.69897 & -8.08 & 2 & RAIN1 & 0 \\
\hline NUM1,3 & -12.75138 & 2.70353 & -4.72 & 3 & RAIN1 & 0 \\
\hline NUM1,4 & -6.03342 & 2.69117 & -2.24 & 4 & RAIN1 & 0 \\
\hline NUM1,5 & -7.28596 & 2.56361 & -2.84 & 5 & RAIN1 & 0 \\
\hline NUM1,6 & -2.86038 & 2.43221 & -1.18 & 7 & RAIN1 & 0 \\
\hline NUM2. & -1.26783 & 1.14070 & -1.11 & 0 & DUM1 & 0 \\
\hline NUM3 & 0.23437 & 1.09256 & 0.21 & 0 & DUM2 & 0 \\
\hline NUM4 & 3.29200 & 1.07962 & 3.05 & 0 & DUM3 & 0 \\
\hline NUM5 & 6.24873 & 1.06476 & 5.87 & 0 & DUM4 & 0 \\
\hline NUM6 & 4.41512 & 1.05036 & 4.20 & 0 & DUM5 & 0 \\
\hline NUM7 & -1.00352 & 1.07464 & -0.93 & 0 & DUM6 & 0 \\
\hline NUME & -5.04584 & 1.09137 & -4.62 & 0 & DUM7 & 0 \\
\hline NUM9 & -5.82971 & 1.11906 & -5.21 & 0 & DUM8 & 0 \\
\hline NUM10 & -5.85377 & 1.13067 & -5.18 & 0 & DUM9 & 0 \\
\hline NUM11 & -2.96688 & 1.13874 & -2.61 & 0 & DUM10 & 0 \\
\hline NUM12 & -1.10625 & 1.15259 & -0.96 & 0 & DUM11 & 0 \\
\hline NUM13 & -0.39156 & 1.14756 & -0.34 & 0 & DUM12 & 0 \\
\hline \multicolumn{7}{|c|}{ Variance Estimate $=3.87080013$} \\
\hline \multicolumn{7}{|c|}{ Std. Error Estimate $=1.96743491$} \\
\hline \multicolumn{7}{|c|}{$A I C=1273.64937$} \\
\hline \multicolumn{7}{|c|}{$S B C=1351.35868$} \\
\hline Number of Resic & & & & & & \\
\hline
\end{tabular}


Table E2. REGION 2: FIRST ARIMA

ARIMA Procedure

Maximum Likelihood Estimation

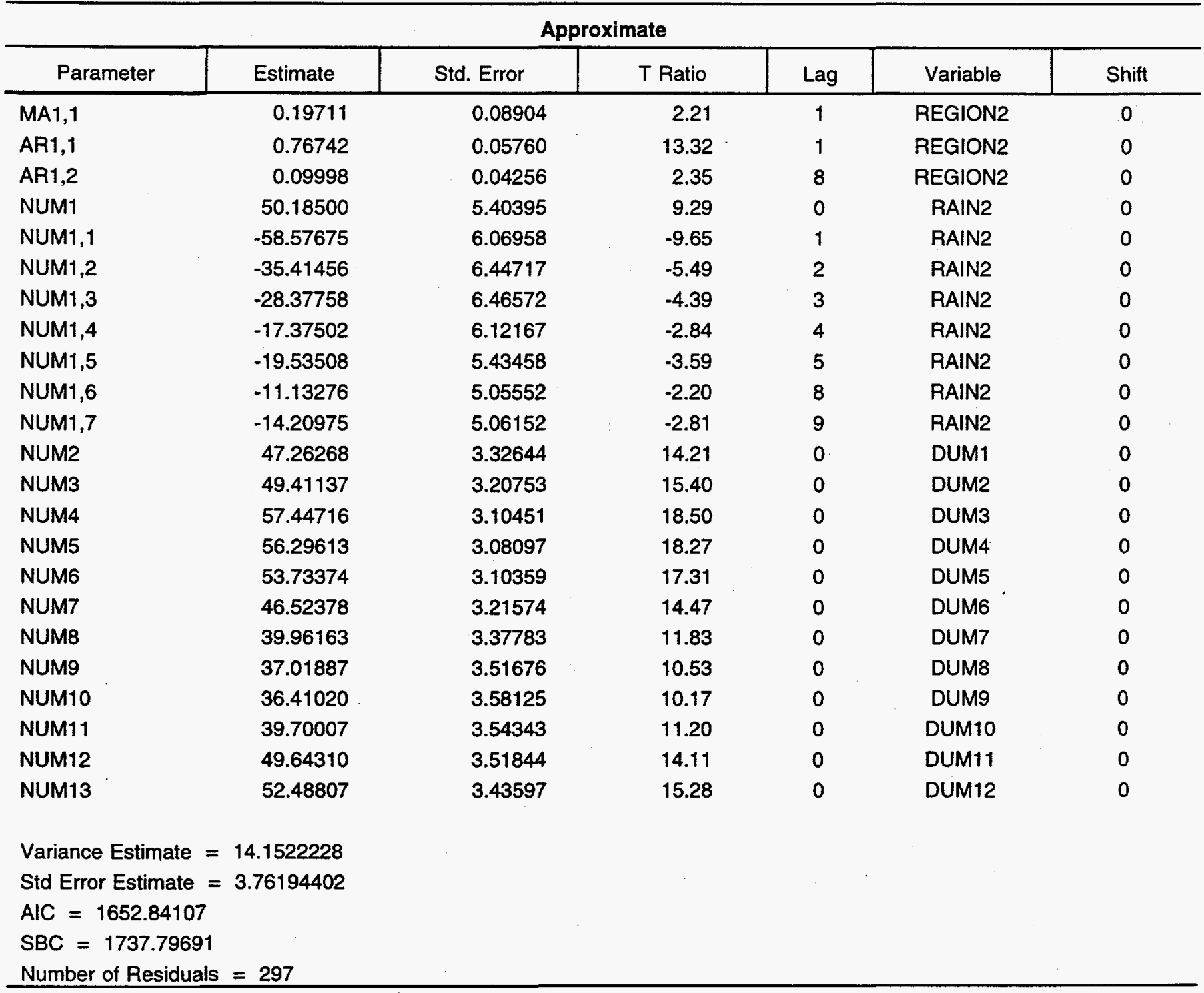


Table E3. REGION 3: FIRST ARIMA

ARIMA Procedure

Maximum Likelihood Estimation

\begin{tabular}{|c|c|c|c|c|c|c|}
\hline \multicolumn{7}{|c|}{ Approximate } \\
\hline Parameter & Estimate & Std Error & T Ratio & Lag & Variable & Shift \\
\hline AR1,2 & 0.17526 & 0.04989 & 3.51 & 5 & REGION3 & 0 \\
\hline NUM1 & 18.58225 & 2.67945 & 6.94 & 0 & RAIN3 & 0 \\
\hline NUM1,1 & -20.76281 & 2.88729 & -7.19 & 1 & RAIN3 & 0 \\
\hline NUM1,3 & -11.46399 & 2.87685 & -3.98 & 3 & RAIN3 & 0 \\
\hline NUM1,4 & -7.76854 & 2.65863 & -2.92 & 4 & RAIN3 & 0 \\
\hline NUM1,5 & -4.17651 & 2.50633 & -1.67 & 6 & RAIN3 & 0 \\
\hline NUM2 & 1.86045 & 0.98655 & 1.89 & 0 & DUM1 & 0 \\
\hline NUM3 & 2.57332 & 0.89401 & 2.88 & 0 & DUM2 & 0 \\
\hline NUM7 & 1.84177 & 1.03064 & 1.79 & 0 & DUM6 & 0 \\
\hline NUMB & -0.82603 & 1.10425 & -0.75 & 0 & DUM7 & 0 \\
\hline NUMO & -1.96818 & 1.15578 & -1.70 & 0 & DUM8 & 0 \\
\hline NUM10 & -0.84953 & 1.19452 & -0.71 & 0 & DUM9 & 0 \\
\hline NUM11 & 0.19339 & 1.17724 & 0.16 & 0 & DUM10 & 0 \\
\hline NUM12 & 1.81097 & 1.14305 & 1.58 & 0 & DUM11 & 0 \\
\hline NUM13 & 1.68889 & 1.08163 & 1.56 & 0 & DUM12 & 0 \\
\hline \multicolumn{7}{|c|}{ Variance Estimate $=2.22688366$} \\
\hline
\end{tabular}


Table E4. REGION 4: FIRST ARIMA

ARIMA Procedure

Maximum Likelihood Estimation

\begin{tabular}{|c|c|c|c|c|c|c|}
\hline \multicolumn{7}{|c|}{ Approximate } \\
\hline Parameter & Estimate & Std Error & T Ratio & Lag & Variable & Shift \\
\hline MA1,1 & -0.12023 & 0.06450 & -1.86 & 11 & REGION4 & 0 \\
\hline MA2,1 & -0.09457 & 0.06356 & -1.49 & 12 & REGION4 & 0 \\
\hline AR1,1 & 0.72888 & 0.04101 & 17.77 & 1 & REGION4 & 0 \\
\hline AR1,2 & 0.07313 & 0.04366 & 1.68 & 8 & REGION4 & 0 \\
\hline NUM1 & -9.16199 & 7.69044 & -1.19 & 0 & RAIN4 & 0 \\
\hline NUM1,1 & -19.73652 & 8.84313 & -2.23 & 9 & RAIN4 & 0 \\
\hline NUM1,2 & -17.07626 & 8.89245 & -1.92 & 10 & RAIN4 & 0 \\
\hline NUM1,3 & -11.97527 & 8.84900 & -1.35 & 13 & RAIN4 & 0 \\
\hline NUM1,4 & -9.74195 & 8.95804 & -1.09 & 14 & RAIN4 & 0 \\
\hline NUM2 & 26.41504 & 2.27566 & 11.61 & 0 & DUM1 & 0 \\
\hline NUM3 & 25.45865 & 2.42980 & 10.48 & 0 & DUM2 & 0 \\
\hline NUM4 & 26.18127 & 2.64931 & 9.88 & 0 & DUM3 & 0 \\
\hline NUM5 & 29.73292 & 2.74400 & 10.84 & 0 & DUM4 & 0 \\
\hline NUM6 & 30.99500 & 2.82142 & 10.99 & 0 & DUM5 & 0 \\
\hline NUM7 & 32.66785 & 2.94100 & 11.11 & 0 & DUM6 & 0 \\
\hline NUM8 & 33.59860 & 2.99140 & 11.23 & 0 & DUM7 & 0 \\
\hline NUM9 & 33.90268 & 2.84048 & 11.94 & 0 & DUM8 & 0 \\
\hline NUM10 & 31.86042 & 2.63381 & 12.10 & 0 & DUM9 & 0 \\
\hline NUM11 & 29.40386 & 2.45551 & 11.97 & 0 & DUM10 & 0 \\
\hline NUM12 & 29.83701 & 2.29628 & 12.99 & 0 & DUM11 & 0 \\
\hline NUM13 & 27.95204 & 2.21046 & 12.65 & 0 & DUM12 & 0 \\
\hline \multicolumn{7}{|c|}{ Variance Estimate $=18.697746$} \\
\hline \multicolumn{7}{|c|}{ Std Error Estimate $=4.32408904$} \\
\hline \multicolumn{7}{|c|}{$A I C=1705.25195$} \\
\hline \multicolumn{7}{|c|}{$S B C=1782.46378$} \\
\hline Number of $R e$ & $=292$ & & & & & \\
\hline
\end{tabular}


Table E5. REGION 5: FIRST ARIMA

ARIMA Procedure

Maximum Likelihood Estimation

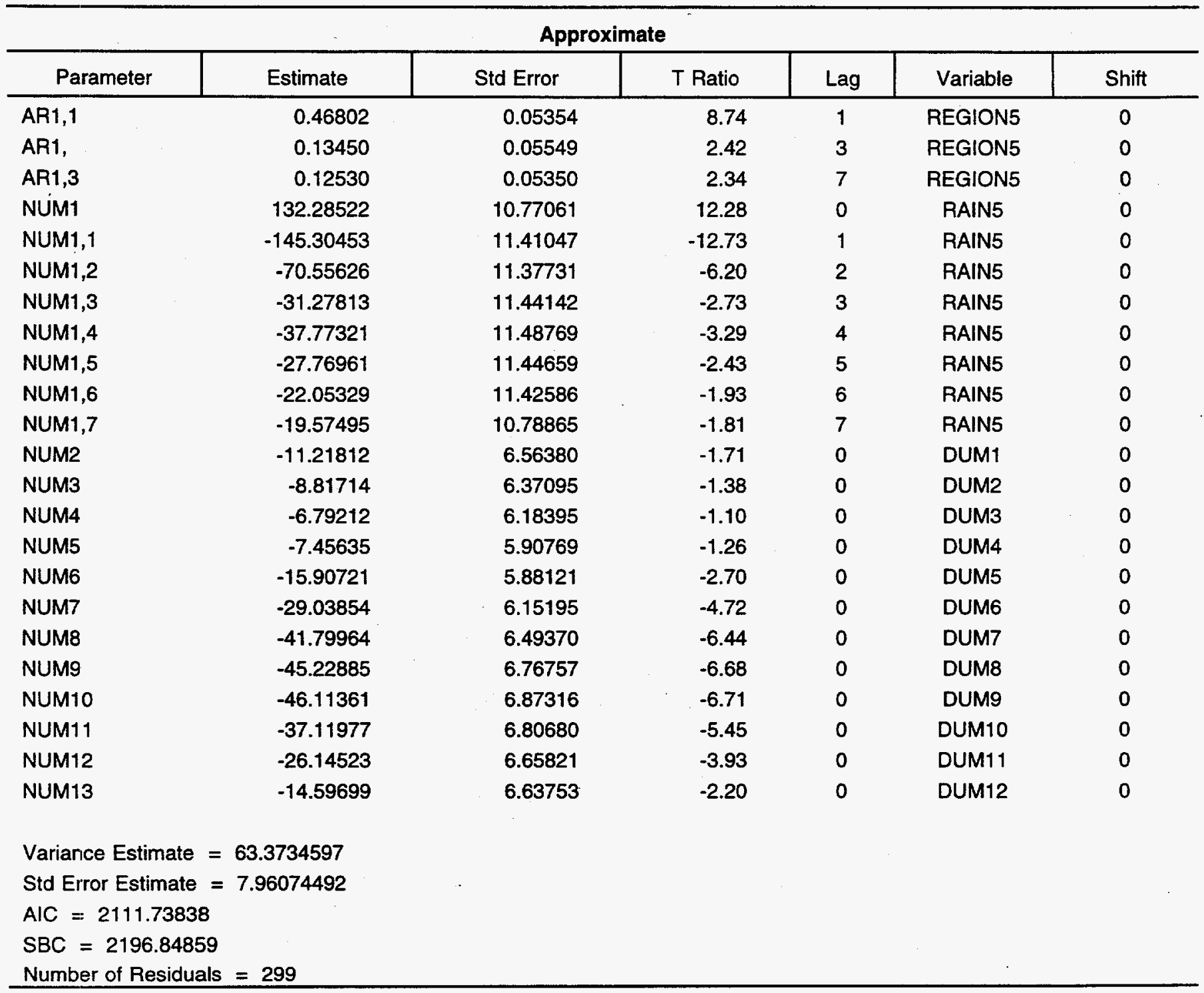


Table E6. REGION 6: FIRST ARIMA

ARIMA Procedure

Maximum Likelihood Estimation

\begin{tabular}{|c|c|c|c|c|c|c|}
\hline \multicolumn{7}{|c|}{ Approximate } \\
\hline Parameters & Estimate & St. Error & T Ratio & Lag & Variable & Shift \\
\hline $\mathrm{AR} 1,1$ & 0.39999 & 0.05959 & 6.71 & 1 & REGION6 & 0 \\
\hline AR1,2 & 0.13812 & 0.05983 & 2.31 & 2 & REGION6 & 0 \\
\hline NUM1 & 127.60369 & 10.72076 & 11.90 & 0 & RAIN6 & 0 \\
\hline NUM1,1 & -131.22813 & 11.06416 & -11.86 & 1 & RAIN6 & 0 \\
\hline NUM1,2 & -70.62778 & 11.34183 & -6.23 & 2 & RAIN6 & 0 \\
\hline NUM1,3 & -58.54659 & 11.30710 & -5.18 & 3 & RAIN6 & 0 \\
\hline NUM1,4 & -59.71659 & 11.08111 & -5.39 & 4 & RAIN6 & 0 \\
\hline NUM1,5 & -27.36970 & 10.73523 & -2.55 & 5 & RAIN6 & 0 \\
\hline NUM1,6 & -10.19426 & 10.25001 & -0.99 & 7 & RAIN6 & 0 \\
\hline NUM2 & 8.87288 & 6.16474 & 1.44 & 0 & DUM1 & 0 \\
\hline NUM3 & 3.93678 & 6.47986 & 0.61 & 0 & DUM2 & 0 \\
\hline NUM4 & -5.68812 & 6.73989 & -0.84 & 0 & DUM3 & 0 \\
\hline NUM5 & -20.64724 & 7.00780 & -2.95 & 0 & DUM4 & 0 \\
\hline NUM6 & -25.46061 & 7.05445 & -3.61 & 0 & DUM5 & 0 \\
\hline NUM7 & -24.93368 & 7.03086 & -3.55 & 0 & DUM6 & 0 \\
\hline NUM8 & -25.22582 & 7.05546 & -3.58 & 0 & DUM7 & 0 \\
\hline NUM9 & -20.66863 & 6.75302 & -3.06 & 0 & DUM8 & 0 \\
\hline NUM10 & -21.93916 & 6.46586 & -3.39 & 0 & DUM9 & 0 \\
\hline NUM11 & -18.82081 & 6.26673 & -3.00 & 0 & DUM10 & 0 \\
\hline NUM12 & -11.71735 & 6.05148 & -1.94 & 0 & DUM11 & 0 \\
\hline NUM13 & -0.07367 & 6.16153 & -0.01 & 0 & DUM12 & 0 \\
\hline \multicolumn{7}{|c|}{ Variance Estimate $=100.811818$} \\
\hline \multicolumn{7}{|c|}{ Std Error Estimate $=10.0405088$} \\
\hline \multicolumn{7}{|c|}{$A I C=2248.39582$} \\
\hline \multicolumn{7}{|c|}{$S B C=2326.10514$} \\
\hline Number of Res & $=299$ & & & & & \\
\hline
\end{tabular}


Table E7. REGION 7: FIRST ARIMA

ARIMA Procedure

Maximum Likelihood Estimation

\begin{tabular}{|c|c|c|c|c|c|c|}
\hline \multicolumn{7}{|c|}{ Approximate } \\
\hline Parameter & Estimate & Std. Error & T Ratio & Lag & Variable & Shift \\
\hline AR1,1 & 0.62490 & 0.04673 & 13.37 & 1 & REGION7 & 0 \\
\hline AR1,2 & 0.08829 & 0.04755 & 1.86 & 7 & REGION7 & 0 \\
\hline NUM1,1 & -83.21246 & 7.86509 & -10.58 & 1 & RAIN7 & 0 \\
\hline NUM1,2 & -56.85843 & 8.16580 & -6.96 & 2 & RAIN7 & 0 \\
\hline NUMI,3 & -38.33788 & 8.16511 & -4.70 & 3 & RAIN7 & 0 \\
\hline NUMI, 4 & -31.96039 & 7.84372 & -4.07 & 4 & RAIN7 & 0 \\
\hline NUM1,5 & -18.55984 & 7.24935 & -2.56 & 5 & RAIN7 & 0 \\
\hline NUM4 & -0.28479 & 2.94580 & -0.10 & 0 & DUM3 & 0 \\
\hline NUM5 & 0.18115 & 2.95732 & 0.06 & 0 & DUM4 & 0 \\
\hline NUM6 & -4.43114 & 3.14464 & -1.41 & 0 & DUM5 & 0 \\
\hline NUM7 & -8.03146 & 3.33700 & -2.41 & 0 & DUM6 & 0 \\
\hline NUM8 & -13.37111 & 3.46792 & -3.86 & 0 & DUM7 & 0 \\
\hline NUM9 & -16.40648 & 3.50933 & -4.68 & 0 & DUM8 & 0 \\
\hline NUM10 & -18.71805 & 3.59181 & -5.21 & 0 & DUM9 & 0 \\
\hline NUM11 & -20.69295 & 3.59412 & -5.76 & 0 & DUM10 & 0 \\
\hline NUM12 & -15.17221 & 3.43924 & -4.41 & 0 & DUM11 & 0 \\
\hline Number of $R e$ & $=299$ & & & & & \\
\hline
\end{tabular}


Table E8. REGION 8: FIRST ARIMA

ARIMA Procedure

Maximum Likelihood Estimation

\begin{tabular}{|c|c|c|c|c|c|c|}
\hline \multicolumn{7}{|c|}{ Approximate } \\
\hline Parameter & Estimate & Std Error & T Ratio & Lag & Variable & Shift \\
\hline MA1,1 & 0.19921 & 0.06561 & 3.04 & 2 & REGION8 & 0 \\
\hline AR1,1 & 0.93694 & 0.02265 & 41.37 & 1 & REGION8 & 0 \\
\hline NUM1 & 17.12660 & 38.01592 & 0.45 & 0 & RAIN8 & 0 \\
\hline NUM1,1 & -77.88977 & 46.84543 & -1.66 & 1 & RAIN8 & 0 \\
\hline NUM1,2 & -80.15278 & 47.42176 & -1.69 & 2 & RAIN8 & 0 \\
\hline NUM1,3 & -124.79380 & 47.20417 & -2.64 & 3 & RAIN8 & 0 \\
\hline NUM1,4 & -135.58321 & 38.29286 & -3.54 & 4 & RAIN8 & 0 \\
\hline NUM1,5 & -43.81052 & 37.74573 & -1.16 & 10 & RAIN8 & 0 \\
\hline NUM1,6 & 13.95544 & 37.45018 & 0.37 & 11 & RAIN8 & 0 \\
\hline NUM2 & 73.81276 & 8.34365 & 8.85 & 0 & DUM1 & 0 \\
\hline NUM3 & 69.57116 & 8.19003 & 8.49 & 0 & DUM2 & 0 \\
\hline NUM4 & 69.15844 & 8.29106 & 8.34 & 0 & DUM3 & 0 \\
\hline NUM5 & 76.01582 & 8.41343 & 9.04 & 0 & DUM4 & 0 \\
\hline NUM6 & 86.45438 & 8.69972 & 9.94 & 0 & DUM5 & 0 \\
\hline NUM7 & 94.08019 & 9.08916 & 10.35 & 0 & DUM6 & 0 \\
\hline NUM8 & 87.97149 & 9.28358 & 9.48 & 0 & DUM7 & 0 \\
\hline NUM9 & 76.25540 & 9.45321 & 8.07 & 0 & DUM8 & 0 \\
\hline NUM10 & 69.60030 & 9.48332 & 7.34 & 0 & DUM9 & 0 \\
\hline NUM11 & 61.14777 & 9.26755 & 6.60 & 0 & DUM10 & 0 \\
\hline NUM12 & 64.15687 & 9.04369 & 7.09 & 0 & DUM11 & 0 \\
\hline NUM13 & 70.59709 & 8.64654 & 8.16 & 0 & DUM12 & 0 \\
\hline \multicolumn{7}{|c|}{ Variance Estimate $=67.1611543$} \\
\hline \multicolumn{7}{|c|}{ Std Error Estimate $=8.19519092$} \\
\hline \multicolumn{7}{|c|}{$A I C=2100.28093$} \\
\hline \multicolumn{7}{|c|}{$S B C=2177.70741$} \\
\hline Number of $R e$ & $=295$ & & & & & \\
\hline
\end{tabular}


Table E9. REGION 9: FIRST ARIMA

ARIMA Procedure

Maximum Likelihood Estimation

\begin{tabular}{|c|c|c|c|c|c|c|}
\hline \multicolumn{7}{|c|}{ Approximate } \\
\hline Parameter & Estimate & Std Error & T Ratio & Lag & Variable & Shift \\
\hline MA1,1 & -0.15148 & 0.06932 & -2.19 & 1 & REGION9 & 0 \\
\hline MA1,2 & -0.19642 & 0.06136 & -3.20 & 4 & REGION9 & 0 \\
\hline MA1, & -0.10936 & 0.06331 & -1.73 & 8 & REGION9 & 0 \\
\hline$M A 1,4$ & 0.11991 & 0.06099 & 1.97 & 15 & REGION9 & 0 \\
\hline MA1,5 & 0.11147 & 0.06059 & 1.84 & 17 & REGION9 & 0 \\
\hline MA2,1 & -0.17778 & 0.06347 & -2.80 & 12 & REGION9 & 0 \\
\hline MA2, & -0.27488 & 0.06253 & -4.40 & 13 & REGION9 & 0 \\
\hline AR1,1 & 0.76305 & 0.04783 & 15.95 & 1 & REGION9 & 0 \\
\hline AR1,2 & -0.11173 & 0.04386 & -2.55 & 9 & REGION9 & 0 \\
\hline NUM1 & 242.86253 & 40.02920 & 6.07 & 0 & RAIN9 & 0 \\
\hline NUM1,1 & -345.00145 & 45.23678 & -7.63 & 1 & RAIN9 & 0 \\
\hline NUM1,2 & -257.94334 & 45.78707 & -5.63 & 2 & RAIN9 & 0 \\
\hline NUM1,3 & -180.91120 & 40.47501 & -4.47 & 3 & RAIN9 & 0 \\
\hline NUM1,4 & -137.11588 & 37.49100 & -3.66 & 5 & RAIN9 & 0 \\
\hline NUM1,5 & 45.68164 & 37.85467 & 1.21 & 9 & RAIN9 & 0 \\
\hline NUM2 & 306.01131 & 18.82996 & 16.25 & 0 & DUM1 & 0 \\
\hline NUM3 & 299.16636 & 20.15721 & 14.84 & 0 & DUM2 & 0 \\
\hline NUM4 & 299.76553 & 19.98029 & 15.00 & 0 & DUM3 & 0 \\
\hline NUM5 & 310.56450 & 19.28665 & 16.10 & 0 & DUM4 & 0 \\
\hline NUM6 & 377.66153 & 17.30740 & 21.82 & 0 & DUM5 & 0 \\
\hline NUM7 & 402.11565 & 15.31178 & 26.26 & 0 & DUM6 & 0 \\
\hline NUM8 & 373.50305 & 14.06109 & 26.56 & 0 & DUM7 & 0 \\
\hline NUM9 & 338.77761 & 14.07950 & 24.06 & 0 & DUMB & 0 \\
\hline NUM10 & 305.19467 & 13.33634 & 22.88 & 0 & DUM9 & 0 \\
\hline NUM111 & 291.72308 & 13.32575 & 21.89 & 0 & DUM10 & 0 \\
\hline NUM12 & 303.40849 & 14.82985 & 20.46 & 0 & DUM11 & 0 \\
\hline NUM13 & 311.66057 & 16.96499 & 18.37 & 0 & DUM12 & 0 \\
\hline \multicolumn{7}{|c|}{ Variance Estimate $=816.414495$} \\
\hline \multicolumn{7}{|c|}{ Std Error Estimate $=28.5729679$} \\
\hline \multicolumn{7}{|c|}{$A I C=2863.23154$} \\
\hline \multicolumn{7}{|c|}{$\mathrm{SBC}=2962.96231$} \\
\hline Number of $R$ & uals $=297$ & & & & & \\
\hline
\end{tabular}

